\title{
NOVOOBJAVENÉ SÍDLISKOVÉ OBJEKTY Z MLADŠEJ FÁZY POLGÁRSKEHO KULTÚRNEHO KOMPLEXU Z DULOVEJ VSI, OKRES PREŠOV ${ }^{1}$
}

\author{
Eva Horváthová - Juraj Malec
}

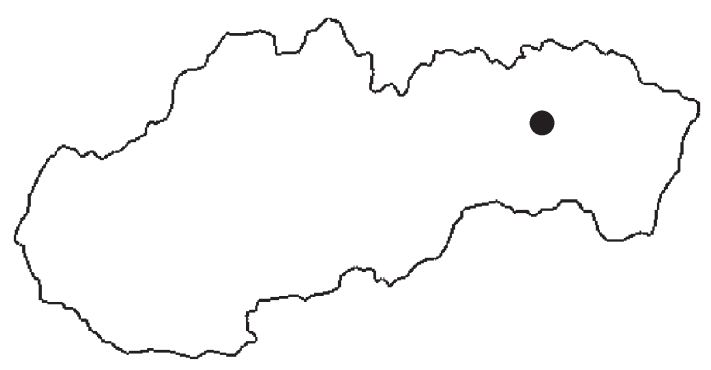

DOI: https://doi.org/10.31577/szausav.2021.68.1

Keywords: Eneolithic, East Slovakia, Lažňany group, Transcarpathian cultural context, Wyciąze-Złotniki group, Lublin-Volhynian culture, Tripolye culture

The newly discovered settlement features from the younger phase of the Polgár cultural complex from Dulova Ves, Prešov district

The settlement features from Dulova Ves are extremely important for the research of interactions of Eneolithic cultures near the Northern Carpathian massive. Their exceptionality is seen in the fact that they have provided us with a unique picture of settlement finds from the youngest horizon of the Polgár cultural complex clearly featuring elements of foreign cultures. Identifying features of the Lažňany group (resp. the Hunyadihalom-Lažňany horizon) prevail in the ceramic material. Foreign attributes show features similar to the pottery of the Lublin-Volhynian culture, WyciążeZłotniki group, and the Tripolye culture. The analyzed finds, thus, at least partly help us create a mosaic of the complex picture of the cultural develompent in the Eneolithic communities living on the interface of the Carpathian Basin and the adjacent areas north of the Western and Eastern Carpathians. Together with the recently published biritual burials from the cemetery in Książnice, site 2 suggest a certain form of symbiosis of the above mentioned cultures (LublinVolhynian and the Hunyadihalom-Lažňany group) which was probably based on the constant demand for the highquality flint raw material as well as the then highly valued copper industry.

\section{ÚVOD DO PROBLEMATIKY}

Aglomerácie sídlisk z doby staršieho eneolitu sú na východnom Slovensku takmer neznáme. Nízka úroveň ich poznania vyplýva zo skutočnosti, že podstatná čast' lokalít z tohto obdobia bola evidovaná len na základe pozitívnych výsledkov povrchovej prospekcie. V poslednom období čoraz častejšie vzbudzujú pozornost' nové objavy solitérnych sídliskových jám, resp. ich menších zhlukov, ktoré boli metodicky odborne preskúmané na viacerých záchranných výskumoch plošne obmedzeného rozsahu (Bidovce, Ruská, Dulova Ves, Vel'ký Šariš). Nálezový materiál pochádzajúci z nich je totožný s horizontom pamiatok skupiny Lažňany, ktorý spolu s kultúrou Hunyadihalom reprezentuje najmladšiu etapu vnútrokarpatského vývoja polgárskeho kultúrneho komplexu.

Z rekonštrukcie osídlenia v okolí strednej a hornej Torysy vo vybraných obdobiach praveku až včasného stredoveku vyplynulo, že v okolí jej monitorovaného povodia v dížke 49,23km k roku 2018 evidujeme 96 archeologických nálezísk. Z nich sa v okrese Prešov na ploche 93282 ha nachádza 43 lokalít (Malček a i. 2018, 21, obr. 2).

Pomyselnú líniu vývoja eneolitu v regióne tvorí 32 nálezísk, ktoré vykazujú identifikačné znaky osídlenia skupiny Lažňany, badenskej kultúry, kultúry Nyírség-Zatín a skupiny Východoslovenských mohýl kultúry so šnúrovou keramikou. Nepochybne poznáme aj niekol'ko d’alších polôh s doloženým eneolitickým osídlením, no nálezy pochádzajúce z nich sú natol'ko málo signifikantné, že ich nedokážeme spolahlivo kultúrne rozpoznat'.

1 Príspevok vznikol s podporou agentúry VEGA 2/0084/18 „Vývoj a premeny sídliskových štruktúr horného Potisia v praveku a v rannej dobe dejinnej“ a Agentúry na podporu výskumu a vývoja APVV-18-0276 „Prostredie a sídliskové siete mladšieho praveku na príklade vybratých období a regiónov Slovenska“. 


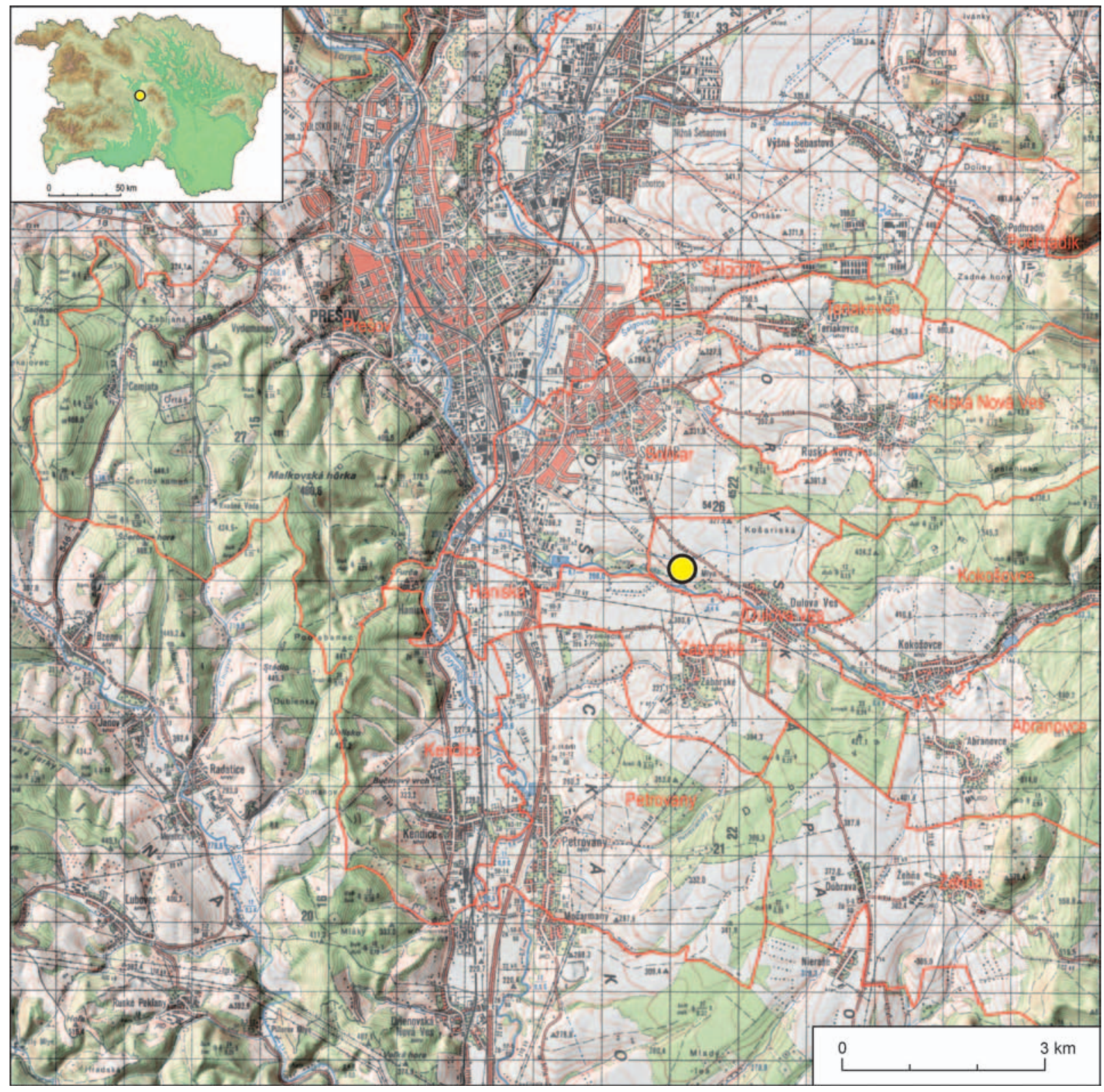

Obr. 1. Obec Dulova Ves, okr. Prešov. Situovanie lokality na slepej mape východného Slovenska a výsek z mapy $1: 10000$.

Primerané reprezentatívne osídlenie viazané na komunikačný koridor stredného povodia Torysy, ${ }^{2}$ vrátane povodia Sekčova, má iba badenská kultúra, ktorej obyvatel'stvo preukázatel'ne osídlilo viac ako 20 polôh (Malček a i. 2018, 36, obr. 5; Malček/Horváthová/Luštíková, v tlači).

Zo Šarišského podolia evidujeme štyri lokality skupiny Lažňany. Dve z nich boli v minulosti zaznamenané v intraviláne Ostrovian ${ }^{3}$ (Kaminská 1983, 125; Lamiová-Schmiedlová 1964, 247; Šiška 1964, 74), d’alšia sa vzṫahuje k Pavlovičovmu námestiu v Prešove (Budinský-Krička 1964, obr. 2) a posledná sa spomína v Šarišských Michalanoch vo Fedelemke (Budinský-Krička 1981, 43; Horváthová 2010, 14; Šiška 1982, 274).

Z okolia Sekčova v súčasnosti sledujeme mierny nárast skúmaných aj novoobjavených sídlisk. Z pohladu výskumu diskontinuity alebo čiastočnej kontinuity osídlenia skupiny Lažňany s badenskou kultúrou sa ako najperspektívnejšia lokalita javí poloha terasy Nad Dzikovým potokom vo Vel'kom Šariši,

2 Severne od jej sútoku so Sekčovom až po obec Ražňany.

3 V polohe I v sonde IIa bola zaznamenaná sídlisková jama skupiny Lažňany (Šiška 1964, 74). 
na ktorú ako prvý upozornil J. Repčák (Blahuta 1963, 169-171; Vizdal/Derfiňák 2006, 213). V. Budinský-Krička konfrontoval eneolitický materiál z tohto sídliska s nálezmi zo žiarového pohrebiska Velikie Lazy v užhorodskom okrese (Budinský-Krička 1964, 87-110). K d’alším evidovaným náleziskám patrí poloha Dubina vo Fulianke a poloha Šarišské lúky v L'uboticiach. Z Fulianky pochádzajú len nepočetné zlomky keramiky zozbierané počas povrchového zberu (Budinský-Krička/Mačala 1990, 42, obr. 11: 12). V L'uboticiach sa na záchrannom výskume, realizovanom v roku 1973, podarilo zdokumentovat štyri sídliskové objekty skupiny Lažňany a jeden sídliskový objekt badenskej kultúry (Šiška 1976, 93). Z najmladšieho horizontu osídlenia polgárskeho kultúrneho komplexu pochádzajú aj sídliskové jamy z Dulovej Vsi. Objavené boli v polohe Ćergov II pred deviatimi rokmi. Ich analýze a vyhodnoteniu sa venujeme v nasledujúcom texte.

\section{ZÁKLADNÉ INFORMÁCIE O LOKALITE}

Obec Dulova Ves sa nachádza na severe Košickej kotliny v časti presahujúcej do šarišského regiónu. Na východnej strane susedí s obcami Kokošovce a Abranovce, na severovýchodnej strane s Prešovom, na severe s Ruskou Novou Vsou a na juhu so Záborským a Žehňou. Zo severovýchodu Dulovu Ves vymedzujú výbežky Slanských vrchov (obr. 1). Vzdialenosṫ od stredu obce k intravilánu Prešova dosahuje 7 km. V rokoch 2012 a 2013 archeologická spoločnost̉ Archeológia Zemplín, s. r. o., pod odborným vedením L. Gačkovej, A. Karabinoša a J. Maleca v lokalite Čergov, v polohách I až III, objavila dovtedy neznáme polykultúrne osídlenie (obr. 2: 1). V súvislosti s ním je nevyhnutné upozornit aj na ned’alekú v chronologickom slede eneolitického vývoja mladšiu lokalitu v polohe Chmelové pri Tichej doline (k. ú. Prešov, čast’ Solivar). Uvedené náleziská sú situované na temene a úpätí toho istého ostrožného výbežku (obr. 2: 2). ${ }^{4}$ Spoločnost' Archeológia Zemplín, s. r. o, v polohe Čergov II, preskúmala osem, resp. devät sídliskových jám, objekty 1, 1A, 2, 3, 4, 5, 6, 7 a 8 (obr. 3). Tri z nich, objekty 1, 1A a 2 obsahovali eneolitický materiál neskorej fázy polgárskeho kultúrneho komplexu. Ďalšie dve sídliskové jamy, objekty 3 a 7 boli pôvodne datované do toho istého sídliskového horizontu, skupiny Lažňany (Malec/Schreiber 2013), avšak analýza materiálu preukázala nutnosṫ korekcie ich datovania do doby halštatskej, z ktorej pochádza aj objekt 6 . Ostatné objekty, 4, 5 a 8 neobsahovali hnutelný archeologický materiál, teda ak neberieme do úvahy drobné kúsky mazanice objavené vo výplni objektu 8 (Malec/Schreiber 2013).

\section{ANALÝZA ARCHEOLOGICKÝCH OBJEKTOV}

Objekty 1 a 2 z Dulovej Vsi (Čergov II), ktoré sa nachádzali od seba vo vzdialenosti 20 m vykazovali viaceré zhody. Mali rozmernejší nepravidelne oválny pôdorys (s maximálnou dížkou od 7,40 do 9 m), mierne šikmé, miestami až kolmé steny a plytké, takmer rovné dno. Každý z nich vo svojom vnútri ukrýval menšiu jamu. V objekte 1 bola takáto jama signovaná ako objekt $1 \mathrm{~A}$ a nachádzala sa pri jeho severozápadnom okraji. V prípade objektu 2 sa ovel’a plytšia jama, bez označenia, vyskytovala v jeho centrálnej časti. Vo výplni oboch objektov bol podobný aj sled zásypových vrstiev. Tie pozostávali z najvýraznejšej hlinitej vrstvy čiernej farby obsahujúcej prímes mazanice a uhlíkov, z vrstvy žltohnedej ílovitej hliny vyskytujúcej sa v niektorých častiach pri stenách jám a napokon aj z vrstvy mastnej ílovitej hliny sivej až hnedosivej farby. Diferenciu sledujeme iba v miere zahĺbenia objektu 1A, ktorý presahoval dno objektu 1 o 0,65 až 0,68 m (obr. 4: 1, 2).

Opísané objekty z mladšej fázy polgárskeho kultúrneho komplexu z Dulovej Vsi sa svojimi pôdorysmi a rozlohou (dosahujúcou 59,43 a 64,75 $\mathrm{m}^{2}$ ) výrazne odlišovali od ostatných objektov zaznamenaných v polohe Čergov II. Nenachádzame $\mathrm{k}$ nim analógie ani medzi chronologicky mladšími eneolitickými objektmi zo susednej lokality Chmelové pri Tichej doline. V konečnom dôsledku k nim

\footnotetext{
4 V rokoch 2009, 2010 a 2019 realizoval Archeologický ústav SAV v polohe Chmelové pri Tichej doline sériu záchranných výskumov v kombinácii s geofyzikálnym prieskumom, pričom zdokumentoval viaceré sídliskové objekty z obdobia neolitu, eneolitu, doby bronzovej a mladšej doby rímskej. Preskúmané eneolitické objekty pochádzajú z osídlenia staršej klasickej fázy badenskej kultúry, ktorej obyvatel'stvo na tomto mieste vybudovalo opevnenú, miestami zrejme len ohradenú osadu s identifikačnými znakmi premyslenej vnútornej zástavby (Horváthová 2015, 381-393; 2016, 99, 100; 2017, 78, 79; Horváthovál Luštíková 2013, 103, 104; 2015, 106; Horváthová/Tirpák 2012, 119-130).
} 

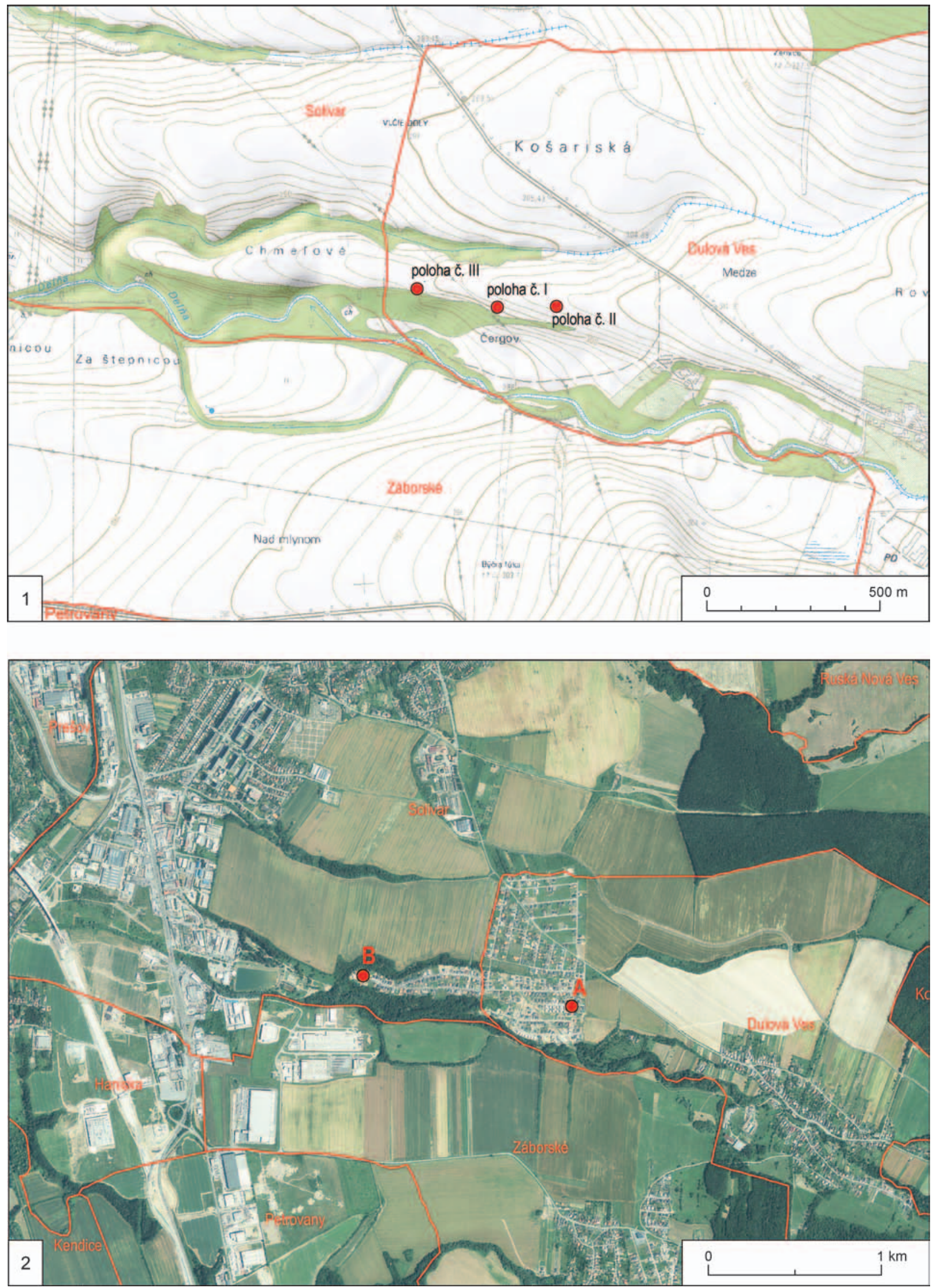

Obr. 2. Lokalizovanie polôh. 1 - mapový podklad; 2 - ortofotomapa. A - Dulova Ves, okr. Prešov, poloha Čergov; B - Prešov, čast’ Solivar, okr. Prešov, poloha Chmelové-Tichá dolina. 


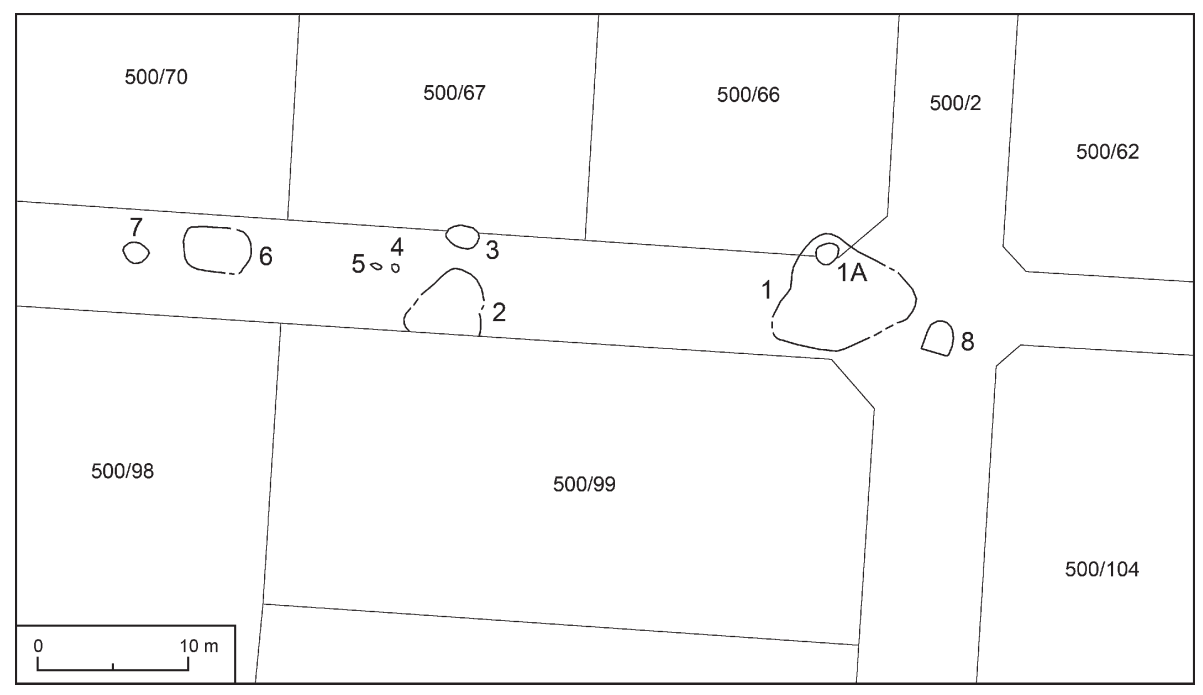

Obr. 3. Obec Dulova Ves, okr. Prešov. Výsek situačného plánu výskumu s vyobrazením miesta nálezu eneolitických objektov 1,1A a 2. Autor plánu J. Malec.

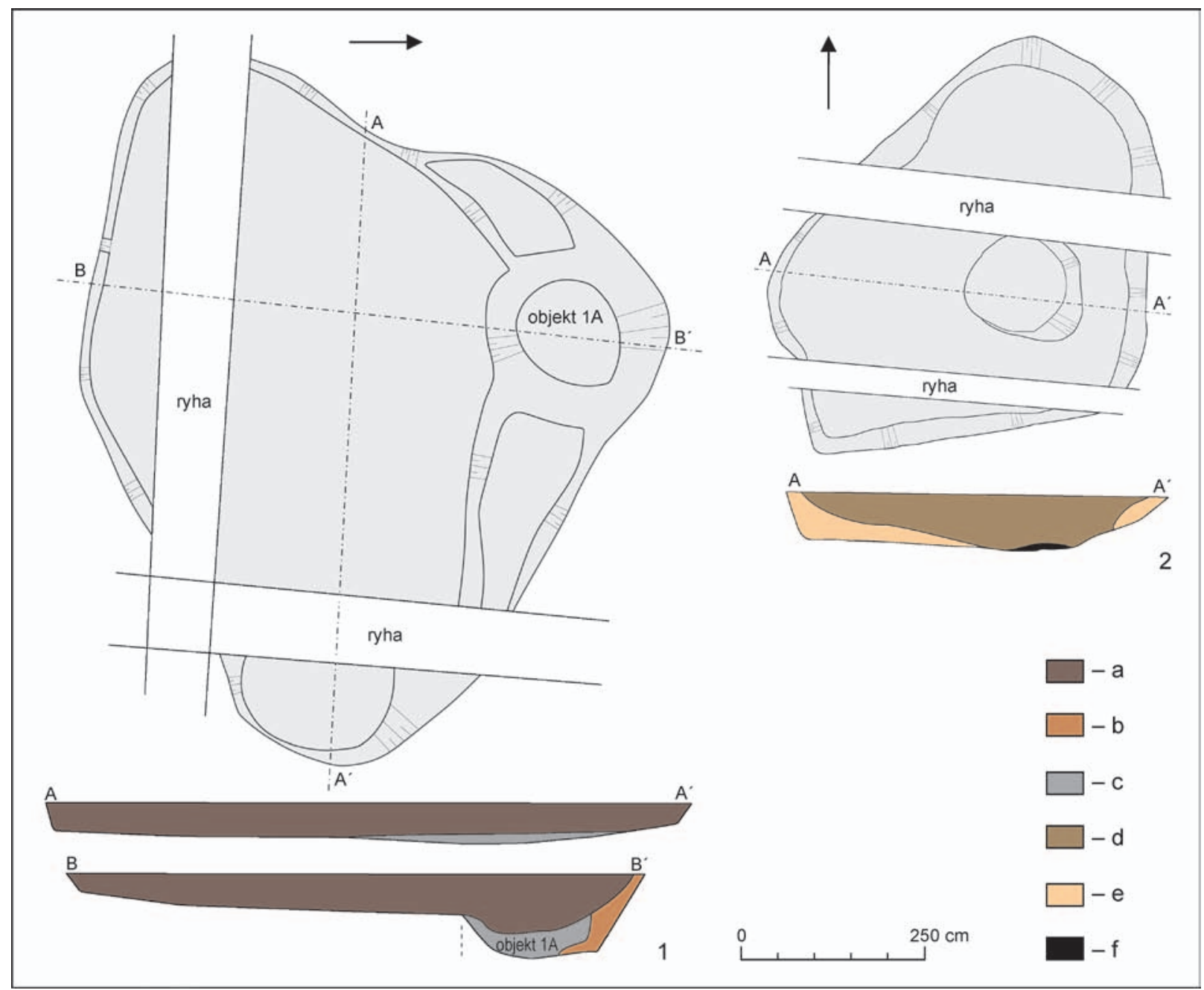

Obr. 4. Obec Dulova Ves, okr. Prešov. 1 - kresbová dokumentácia objektov 1 a 1A; 2 - kresbová dokumentácia objektu 2. Legenda: a - čiernosivá hlina s prímesou mazanice a uhlíkov; b - žltohnedá ílovitá hlina; c - sivá ílovitá hlina; $\mathrm{d}$ - sivohnedá hlina s prímesou mazanice a uhlíkov; e - žltohnedá premiešaná hlina; f - hnedosivá mastná hlina. 
doposial nepoznáme paralely $\mathrm{v}$ celom posudzovanom mikroregióne $\mathrm{v}$ okolí stredného toku Torysy. Ich pôdorysy sú len čiastočne podobné objektu 94 lažnianskej skupiny z obce Ruska situovanej na východnej hranici Michalovského okresu (Horváthová/Gačková 2019, 233, 236, 237, tab. VI).

Objekty 1 a 2 z Dulovej Vsi vykazujú rysy plytších a rozmerných solitérnych jám nepravidelne oválnych tvarov. Vzhladom $\mathrm{k}$ tomu, že $\mathrm{v}$ ich vnútri a ani v ich najbližšom okolí neboli rozpoznané prepálené plochy indikujúce výskyt tepelných telies, nemožno ich explicitne interpretovat' ako pozostatky obytných stavieb.

\section{ANALÝZA ARCHEOLOGICKÉHO MATERIÁLU}

Z analyzovaných sídliskových objektov pochádza 2427 archeologických nálezov, z ktorých relevantnú väčšinu tvoria zlomky keramických nádob (spolu 2413 ks). Ostatné nálezy pozostávajú $\mathrm{z}$ drobných predmetov vyrobených z hliny (4 ks) a kameňa $(7 \mathrm{ks})$. V zásypových vrstvách sídliskových jám sa spolu s črepmi vyskytovali aj nevýrazne kúsky prepálenej hliny a kamenná surovina. Organický materiál absentoval.

Keramika sa zväčša zachovala vo výrazne torzovitom stave bez možnosti jej priradenia ku konkrétnemu typu nádoby (obr. 5). Pri väčšine úlomkov sme mali možnost' rozlíšit iba hrúbku keramickej steny, jej povrchovú úpravu a kvalitu výpalu. Do skupiny tenkostennej stolovej keramiky sme zaradili črepy s hrúbku stien od 0,2 do $0,4 \mathrm{~cm}$. Zistili sme, že počet črepov z tenkostenných nádob je neúmerne nižší v porovnaní s počtom črepov pochádzajúcich zo stredne hrubej až hrubostennej keramiky (obr. 6). Mohlo by to naznačovat', že v celkovom keramickom fonde sídliska mohli mat väčšie a objemnejšie nádoby s hrubšími stenami početnejšie zastúpenie. Mocnost’ stien takýchto nádob dosahovala od 0,5 do $1 \mathrm{~cm}$.

Podrobnejšiu analýzu keramického materiálu sme uskutočnili len na vzorke 115 keramických zlomkov, ktorých zachovaná profilácia a niektoré výzdobné prvky aspoň čiastočne umožnili porovnat ich so škálou hrnčiarskych výrobkov skupiny Lažňany, resp. kultúry Hunyadihalom (obr. 7). Výber archeologického materiálu sprístupňujeme $\mathrm{v}$ grafickom vyobrazení v tabul'kách I až VII.

Možno konštatovat', že z typologickej zostavy keramického nálezového súboru boli na sídlisku v Dulovej Vsi používané misy, šálky, hrnce, amfory/amforky, nádoby štvorhranného tvaru, delené nádoby, zásobnicové nádoby a pokrievky. Vyskytol sa aj jeden fragment pochádzajúci z atypickej nádoby oválneho tvaru s ulomenou dutou nôžkou a s väčším otvorom na dne (tab. VII: 4). Ak v skupine detailnejšie analyzovanej keramiky zohladníme početnost̉ zastúpenia jednotlivých zlomkov nádob s možnostou priradenia ich ku konkrétnemu typu hrnčiarskeho produktu, tak v objekte 1 jednoznačne dominovali zlomky mís a hrncov. Z d’alších nálezov boli identi-
Obr. 5. Východiskový stav analyzovanej keramiky z objektov 1, 1A a 2.

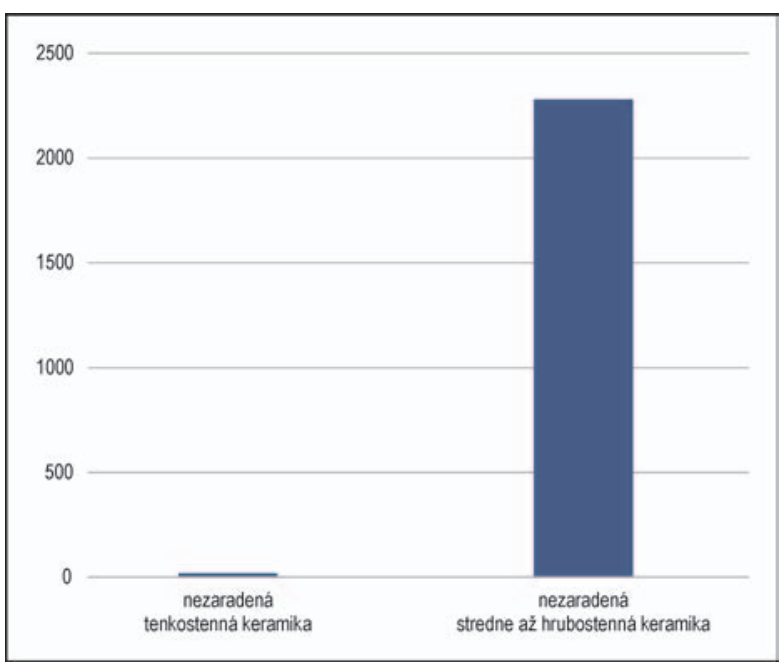

Obr. 6. Porovnanie početnosti nezaradenej keramiky z objektov 1, 1A a 2 s ohladom na hrúbku keramickej hmoty. 


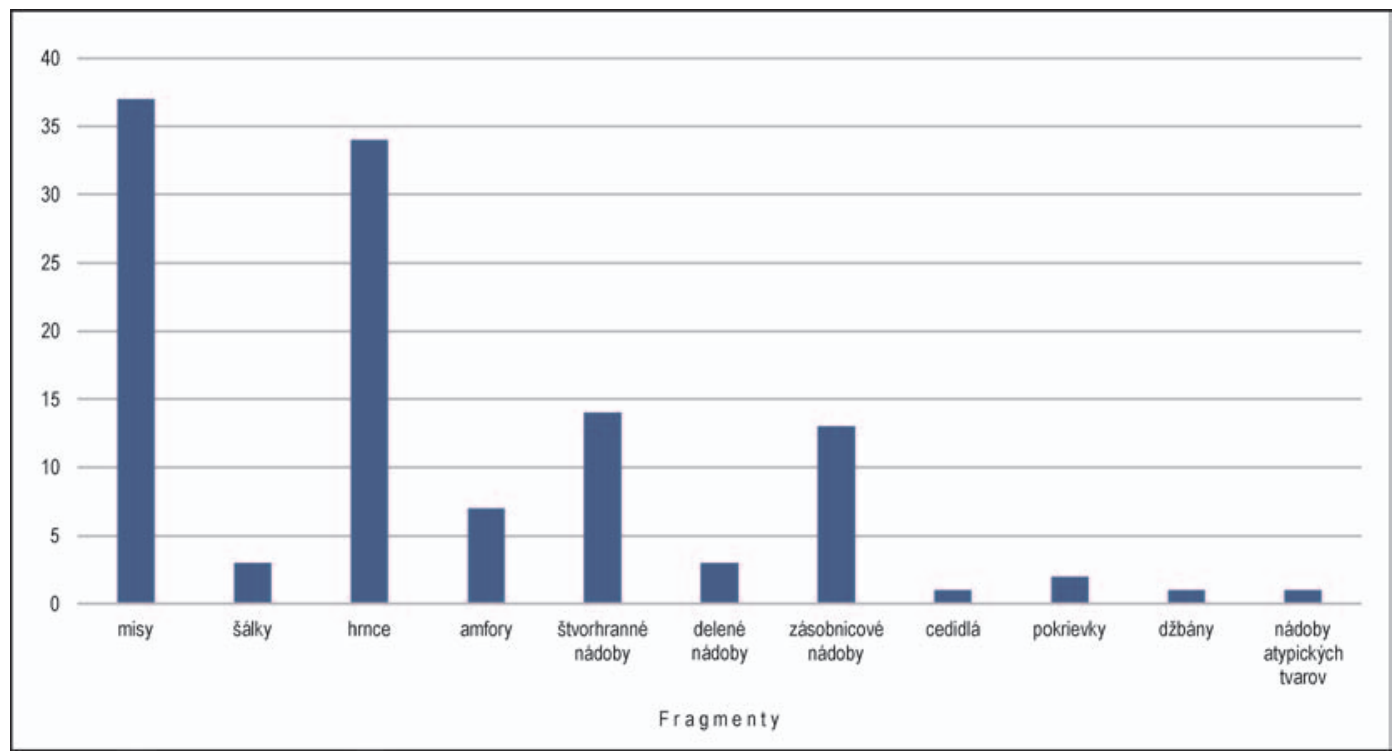

Obr. 7. Zastúpenie identifikovaných keramických typov nádob v objektoch 1, 1A a 2.

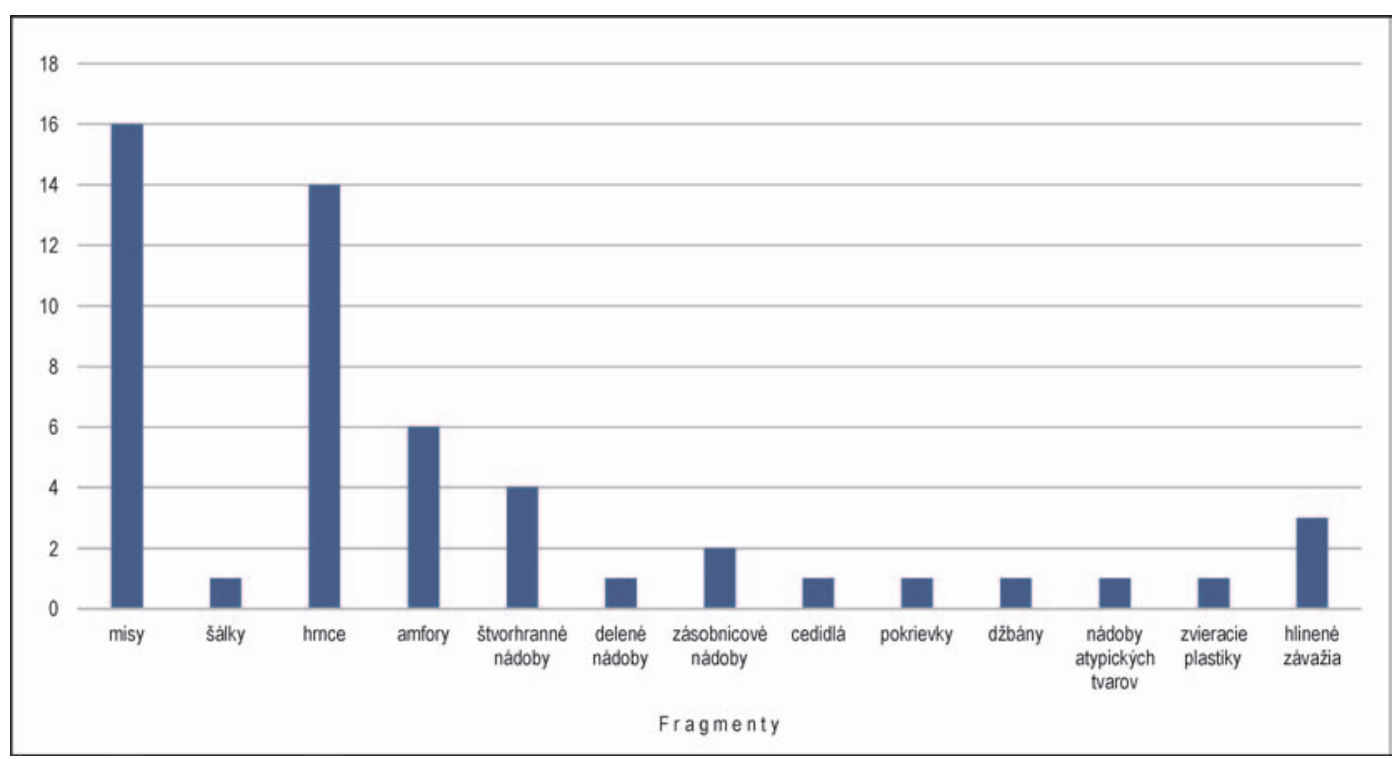

Obr. 8. Zastúpenie identifikovaných keramických typov nádob a drobných predmetov v objekte 1.

fikované fragmenty amfor, štvorhranných nádob, zásobnicových nádob, delenej nádoby, pokrievky a atypickej nádoby neznámej funkcie. $Z$ drobných hlinených predmetov sa v objekte 1 nachádzali časti najmenej dvoch praslenov, fragment predmetu neznámeho účelu a prekvapivo aj bez hlavy zachovaná zoomorfná plastika (obr. 8). Z výplne toho istého objektu pochádzajú aj dva diskutabilné črepy. Prvý z nich pripomína fragment cedidla a ten druhý pochádza z vyspelej formy džbánu so širším pásikovým uchom.

V objekte 1A rovnako prevažovali torzá mís. Medzi d’alšími črepmi boli rozpoznané zlomky hrncov, zásobnicových nádob a štvorhranných nádob (obr. 9). V objekte 2 spolu s nezaradenou keramikou počtom mierne prevyšovali fragmenty hrncovitých nádob. Ostatné črepy pochádzali z mís, nádob štvorhranného tvaru, zásobných nádob, delených nádob, šálok a po jednom črepe je doložený výskyt amfory a pokrievky (obr. 10). 


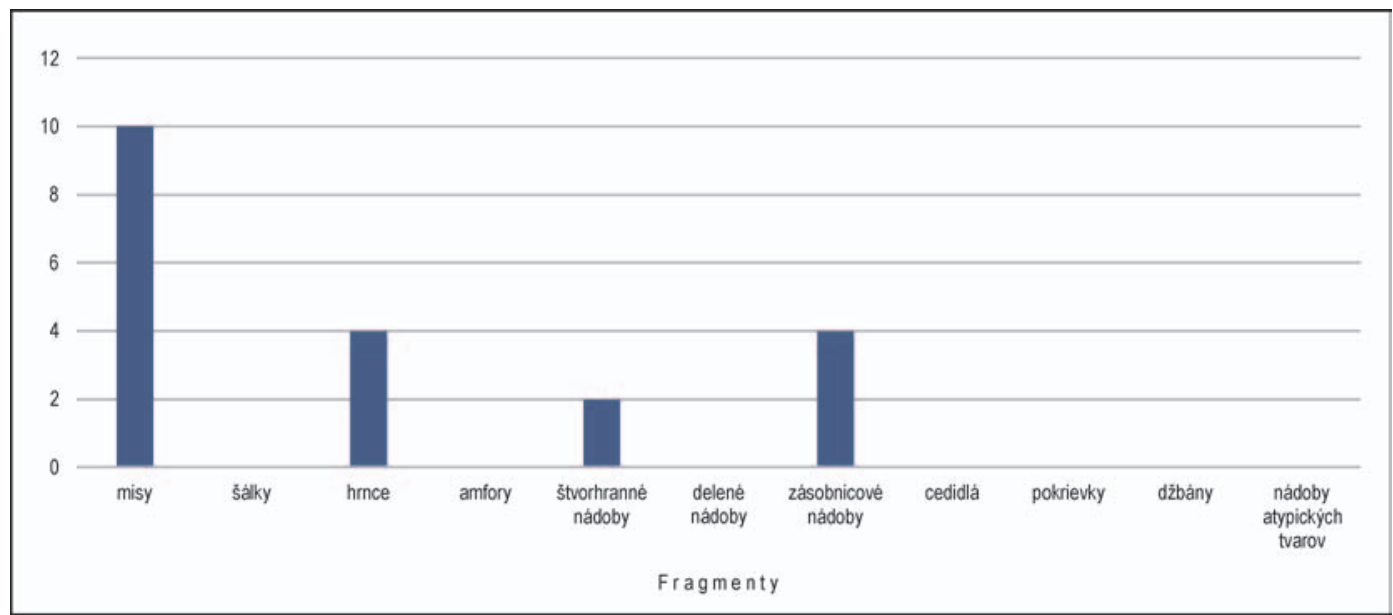

Obr. 9. Zastúpenie identifikovaných keramických typov nádob v objekte 1A.

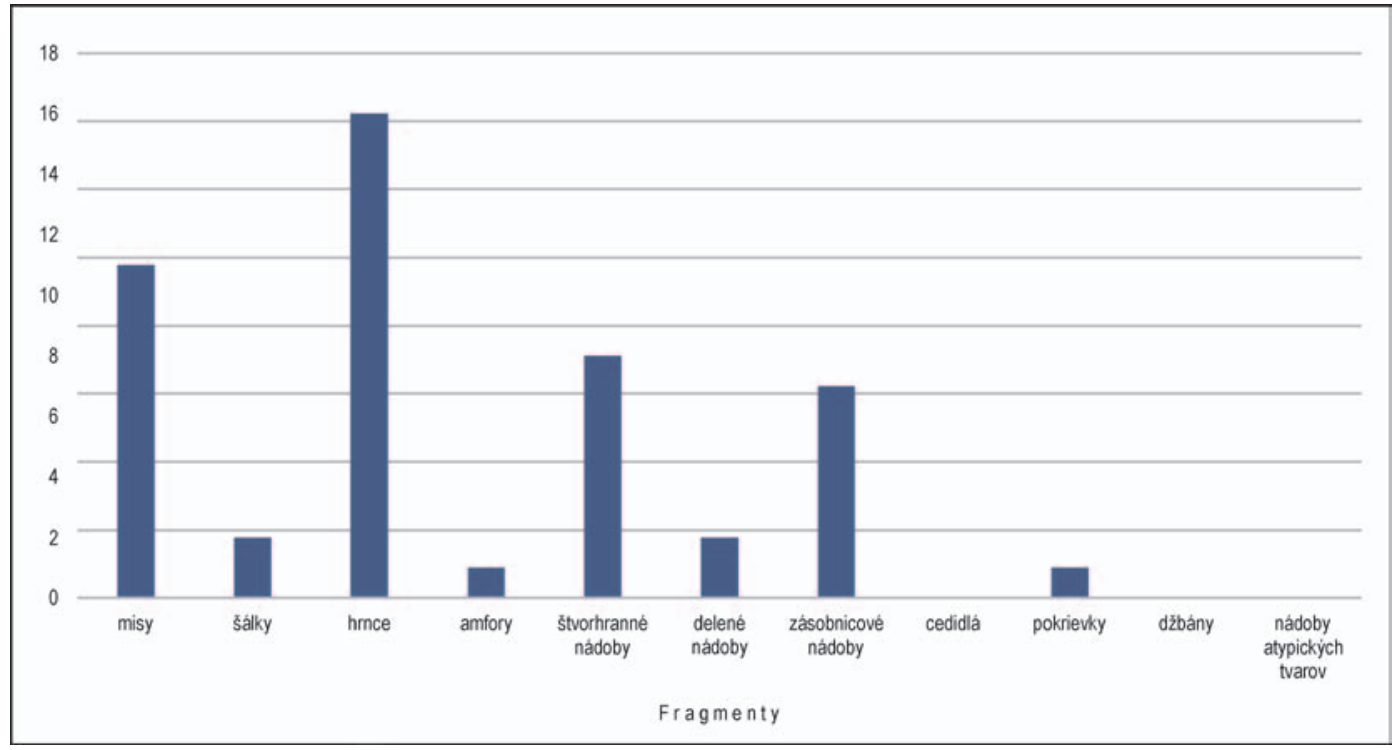

Obr. 10. Zastúpenie identifikovaných keramických typov nádob v objekte 2.

\section{Keramika}

\section{Šálky}

Z objektu 2 pochádzajú fragmenty dvoch tenkostenných šálok s esovitou profiláciou, nízkym, len naznačeným hrdlom a baňatým telom. Ich dno sa nezachovalo (tab. II: 1, 2). Črep z okraja tretej šálky sa vyskytol aj v objekte 1 (tab. V: 2). Zmienené nálezy majú precízne vyhladené steny bez náznakov výzdoby. Na ich vonkajšej strane sa zachovala vrstva tenkého hlineného náteru tmavohnedej farby.

Na území východného Slovenska sa najstarší exemplár šálky spája s potiskou kultúrou ${ }^{5}$ (Vizdal 1980, 38, tab. XXII: 3). Ako samostatný keramický typ začali byt̉ nádoby vo vel'kosti a v tvare šálok používané až s nástupom kultúr polgárskeho komplexu. Ich počiatočné podoby, známe od prototisza-

\footnotetext{
5 Miniatúrna nádobka v tvare šálky, kultový objekt A/76, Čičarovce.
} 
polgárskej fázy ${ }^{6}$, si zachovali tvary mís, od ktorých sa odlišovali iba menšími rozmermi a tenšími stenami. Obdobne ako misovité nádoby boli aj šálky zdobené polgulovitými alebo hrotitými výčnelkami (Kaminská 2010, 26, 35; Raczky/Siklósi 2013, obr. 3: g; Šiška 1968, obr. 35: 2, 3, 6).

Pamiatky bodrogkeresztúrskej kultúry sa na spomínanom území objavujú len vel’mi sporadicky. Na lokalitách vnútrokarpatského priestoru ich rozoznávame na základe výskytu tzv. mliečnikov, ktoré mali vysoké hrdlo a dve malé uchá pri okraji. Ďalším indikátorom ich kultúrneho určenia je rytá výzdoba v podobe meandrov, ktoré sa striedajú s nezdobeným vyhladeným povrchom (Patay P. 1974; 2005, 94, obr. 75; 76). Napriek častému používaniu nádob v tvare šálok od počiatočných vývojových etáp kultúr polgárskeho komplexu sa ich výskyt na konci tohto vývoja minimalizuje. Tento jav sledujeme najmä na lokalitách skupiny Lažňany, kde sa šálky v doposial' preskúmaných hroboch a sídliskových objektoch nenachádzali (Horváthová/Gačková 2019, 273; Šiška 1970, 29-31; 1972, 129, 130; 1976, 94, 95). V analyzovaných súboroch z Čergova sa nám teda javia ako nový, skupine Lažňany nevlastný keramický prvok. Zo susednej sídliskovej zóny, obývanej kultúrou Hunyadihalom, sa v skupine velmi jemnej keramiky objavujú viaceré varianty šálok (Patay P. 2005, 79, 81; tab. 15: 11, 20; 22: 7, 8). Im verné analógie nachádzame aj v periférnej zóne lengyelsko-polgárskeho kultúrneho vplyvu, menovite v nálezových súboroch z mladšej fázy lubelsko-wołyńskej kultúry (Modlniczka, poloha 2, Czekaj-Zastawnyl Przybyła 2012, 203, obr. 65: 2; Bronocice, Kruk/Milisauskas 1985, tab. 12: 2; Książnice, poloha 2, Wilk 2004, obr. 3: 3; 4: 2; 7: 3; Strzyżów, Zakościelna 2006, obr. 4: 11; Złota-Grodzisko II, Zakościelna/Matraszek 2007, 414, obr. 7: 15), v pleszowsko-modlnickej skupine (Kraków, čast’ Nowa Huta, poloha Pleszów, Kulczycka-Leciejewiczowa 1969, tab. XXXII: 14, 17; Ojców, jaskyňa Ciemna, Rook 1980, tab. IV: 8) a taktiež v skupine Wyciąże-Złotniki (Kraków, čast̉ Nowa Huta, poloha Wyciąże, Kozłowski 1968, tab. XIII: 6, 10, 11). Śálky hruškovitého tvaru sú velmi charakteristické obzvlášt pre lubelsko-wołyńsku kultúru, hoci ich podiel v jej III. vývojovej fáze podliehal zjavnému poklesu (Zakościelna 2006, 84, 85). Existujú však lokality, ako napr. pohrebisko v Ksiąžnicach, poloha 2, kde šálky tvorili štandardnú výbavu každého hrobu (Wilk 2004, obr. 3: 3; 4: 2; 7:3).

\section{Misovité nádoby}

Z identifikovaných foriem keramiky tvoria misovité nádoby najväčší podiel zodpovedajúci 32,17 \%. Ich kresbovo rekonštruované fragmenty dokumentujú výskyt nádob s velmi zaobleným telom a výrazne odsadeným hrdlom, ktoré mali cylindrický alebo mierne lievikovitý tvar (tab. I: 2-4; 2: 3; 5: 3). V predchádzajúcich kultúrach polgárskeho komplexu boli nádoby v tejto podobe zriedkavé. Častejšie sa začali vyskytovał až v najmladších hroboch na pohrebisku v Tiszapolgári-Basatanyi (Bognár-Kutzián 1963, tab. CXIII: 13, 14), no s nástupom materiálnej kultúry skupiny Lažňany sa ich produkcia výrazne zvýšila (Horváthová/Gačková 2019, tab. VII: 3, 4; Šiška 1972, tab. III: 3; VI: 7; VII: 2, 6; X: 2, 9, 12). Im podobné exempláre vieme doložit v kultúre Hunyadihalom (Patay P. 2005, tab. 37: 8; 47: 6) ako aj v skupine Wyciąże-Złotniki (Kulczycka-Leciejewiczowa 1969, tab. XXXIX: 15).

Na povrchu niektorých črepov, pochádzajúcich z mís vyššie uvedenej profilácie, sa nachádza jednoduchá výzdoba v podobe zaoblených plastických výčnelkov (tab. I: 2) a naznačených plytkých jamiek (tab. I: 4). K výraznejším dekoratívnym prvkom patria z vnútornej strany stien vytlačené vypukliny (tab. V: 3), ktoré sa v kultúre Hunyadihalom ako aj v skupine Lažňany objavujú aj na amforách (Patay P. 2005, tab. 14: 6; 37: 12; Šiška 1972, obr. 29: 1, 6; 30: 2, 7; tab. III: 1, 10; XI: 5, 11; XII: 3). V skupine Lažňany sa nádoby s identickou výzdobnou technikou vyskytovali takmer na všetkých doposial skúmaných lokalitách (Malé Zalužice-Lažňany a Vel'ký Šariš, Budinský-Krička 1964, 88; Ruská, Horváthová/Gačková 2019, tab. V: 4, 7; Košice, čast Barca, poloha Svetlá IV, Šiška 1970, 29, obr. 1; Šebastovce, Šiška 1972, 130, obr. 29: 2, tab. IV: 8). V skupine Wyciąże-Złotniki sa zvnútra vytlačené výčnelky objavili na keramike z lokality Bodzanów (Kaczanowska/Tunia 2009, obr. 67: 2), v lubelsko-wołyńskej kultúre na lokalite Książnice, poloha 2 (Wilk 2016, 14, obr. 7: c), v Mad’arsku ich evidujeme z pohrebiska Bodrogkeresztúr vo Fényeslike (Patay P. 1968, tab. VII: 5; IX: 10), no známe sú aj z Dolného Rakúska z Puch-Scheibenfeld, kde sa tento typ výzdoby uplatnil v sprievode keramiky zdobenej technikou brázdeného vpichu (Ruttkay 2006, obr. 3: 4a).

Odlišný tvar mali keramické formy nádob bez hrdla so širokým ústim a mierne zaoblenými alebo kónickými stenami, ktorých okraje sa vo viacerých prípadoch zdobili rozmanito vhíbenými jamkami alebo zásekmi (tab. I: 5, 6; II: 6; IV: 1-4; V: 1). Na území Košickej kotliny je tento výzdobný prvok vlastný prevažne

\footnotetext{
6 Vrátane celého trvania tiszapolgárskej kultúry.
} 
hrncovitým nádobám (Budinský-Krička 1969, 232, 234, obr. 1: 5, 6, 9; Šiška 1972, tab. IV: 1; V: 14, 16; VI: 3; VII: 1, 3, 7; IX: 3; X: 8, 11, 13; XI: 4, 7, 8, 10). Zhodu s takto dekorovanými okrajmi nádob nenachádzame len na sídliskách kultúry Hunyadihalom, ale opät aj na odvrátenej strane Západných Karpát v zóne osídlenia lubelsko-wołyńskej kultúry (Kruk/Milisauskas 1985, obr. 23: I: 8; IV: 3, 4, 6-8; Patay P. 2004, obr. 13: 6, 14: 4, 7, 8, 10; 2005, tab. 17: 1, 3; 28: 10; 31: 1, 3, 4, 6, 10, 11; 32: 6; 39: 7a, 7b; 49: 6; 55: 5). Zrejme od jej kultúrneho vplyvu možno odvodit aj dalšie varianty dekorovania keramiky v podobe hrotitých alebo jazykovitých výčnelkov presahujúcich okraje nádob (tab. II: 5; V: 10). Ich viaceré podoby sa objavujú na keramike z lokalít Gródek 1C (hroby 2/1987 a X/1993; Zakościelna 2010, tab. Xa: 10; IXa: 6), Modlniczka poloha 2 (objekty 716 a 796; Czekaj-Zastawny/Przybyła 2012, obr. 65: 1; tab. 71: 1; 73: 3), Targowisko polohy 10, 11 (Zastawny/ Grabowska 2014, tab. 3: a) a d’alších.

\section{Hrnce}

K druhej najpočetnejšej skupine nálezov patria úlomky hrncovitých nádob, ktoré z identifikovaných foriem hrnčiarskych výrobkov tvoria $29,57 \%$. Kresbovo sa podarilo zrekonštruovat iba hornú čast jedného hrnca so slabo zaoblenými stenami a krátkym valcovitým hrdlom (tab. II: 4). Zlomky z d’alších nádob patrili hrncom s mierne rozšíreným alebo len naznačeným hrdlom (tab. IV: 9; V: 5). Pri ich okraji sa nachádzali hrubšie formované uchá (tab. IV: 7, 8, 12, 13), ktoré sú v rámci horizontu pamiatok polgárskeho kultúrneho komplexu charakteristické predovšetkým pre materiálnu kultúru skupiny Lažňany a v takmer identickej podobe sa objavujú aj na lokalitách kultúry Hunyadihalom (Patay P. 2005, tab. 41: 1, 3, 5, 6; 42: 1, 5; Patay R. 2004, obr. 13: 4, 5, 11; Šiška 1971, 131). Okraje hrncov boli podobne ako okraje hlbokých mís dekorované jamkami alebo ryhami (tab. V: 5).

\section{Amfory/amforky}

Amfory spoločne s misami a hrncami patrili k štandardnej výbave kuchynskej keramiky skupiny Lažňany. Z identifikovaných črepov z Dulovej Vsi tvoria necelých 7 \%. Ich prvý variant (Ia), ktorý sa $\mathrm{v}$ analyzovanom keramickom súbore nevyskytol, zodpovedá nádobám s cylindrickým alebo mierne kónickým hrdlom, širším baňatým telom a dvomi zaoblenými uchami prečnievajúcimi nad okraj (Šiška 1972, 132, obr. 29: 3). Obmeny podobných nádob nachádzame už v bodrogkeresztúrskej kultúre, rovnako aj na lokalitách skupiny Wyciąże-Złotniki a lubelsko-wołyńskej kultúry (Czekaj-Zastawny/Przybyła 2012, 177, obr. 52: 3, 4; tab. 69: 5; Zakościelna 2006, 85, 88, obr. 4: 5-7). Druhý variant amfor (Ib) sa od predošlého variantu odlišuje umiestnením a tvarom úch, ktoré boli situované na rozhraní hrdla a tela alebo na baňatom tele. Možno s ním spojit tri zlomky črepov, objavené vo výplni objektu 1 (tab. V: 6, 9 , 13). Na prvom z nich je zmena profilácie medzi hrdlom a telom zvýraznená plytkým žliabkom (tab. V: 6). Nádoby podobné amforám variantu Ib boli identifikované aj v kultúre Hunyadihalom, avšak $\mathrm{s}$ tým rozdielom, že ich kónické hrdlá sú v porovnaní s amforami skupiny Lažňany užšie a vyššie (Patay P. 2005, tab. 6-8).

\section{Zásobnicové nádoby}

Zo súboru typologicky identifikovanej keramiky zodpovedajú zlomky zásobnicových nádob minimálne 11,3\%. Na výskyt tohto typu keramiky, okrem hrubostenných (nie vždy typologicky zaradených) črepov, poukazujú aj nálezy mohutných úch člnkovitého tvaru, ktoré boli spravidla situované na maximálnu vydutinu alebo pod vydutinou tela nádoby (tab. V: 12; Šiška 1972, 135, tab. III: 9, 11, 14; IV: 10; X: 7). V geografickom priestore severného Potisia sa podobné tvary úch vyskytovali na keramike z neskorého neolitu, na začiatku staršieho eneolitu s prevahou v prototiszapolgárskej fáze a ako výzdobný element sa ujali aj na nádobách kultúry Hunyadihalom (Paty P. 2005, 104, tab. 46: 6, 8; Šiška 1964, 197, obr. 12: 27; 25: 24; 1968, 78, 104, 111, obr. 5: 9, 12, 14; 6: 10; 9: 13, 14). Severne od centrálneho územia polgársko-lengyelských kultúr sa uchá modelované do člnkovitého tvaru objavujú aj na keramike západomalopolských neolitických kultúrnych skupín, medzi ktoré patrili aj skupina pleszowsko-modlnicka lengyelskej kultúry a polgárska skupina Wyciąże-Złotniki (Czekaj-Zastawny/Przybyła 2012, 144, 180, obr. 40: 13, tab. 53: 5; 55: 5). Evidujeme ich aj v hrnčiarstve lubelsko-wołyńskej kultúry (Kruk/Milisauskas 1985, 57, tab. VIII: 2, 4 ; obr. 22c: 2,4$)$. 


\section{Nádoby štvorhranného tvaru}

Na základe doterajších poznatkov o sporadickom výskyte štvorhranných kalichov na lokalitách skupiny Lažňany je prekvapivé, že na sídlisku v Dulovej Vsi sa ich zlomky nachádzali vo všetkých troch analyzovaných sídliskových jamách (obr. 7-10). Z rozlíšitelných foriem keramiky na tomto sídlisku ich fragmenty tvoria 12,17 \% (obr. 7). Zachovali sa ich horné časti v podobe lalokov, ktoré pôvodne prečnievali nad okraj nádoby (tab. V: 4; VI: 1, 2), ako aj ich dolné časti s doložením hranatého dna, prípadne z neho vychádzajúcej steny (tab. VI: 5, 8-10, 12). Na jednom z črepov sa v mieste hrany dvoch zbiehajúcich stien podarilo rozlíšit zvislo modelovanú plastickú lištu, ktorá vzdialene pripomína výzdobu, aplikovanú na tomto type keramiky z komplexu sídliskových jám z Ruskej (tab. VI: 8; Horváthová/Gačková, 2019, tab. V: 16; VI: 3, 6). Prezentovaný plastický dekór sa omnoho častejšie ako v sledovanej kultúrnej skupine vyskytoval na keramike kultúry Hunyadihalom (Patay P. 2005, tab. 19: 4, 7; 20: 4; 21: 9, 11, 13). Zlomky horných častí kalichov z Dulovej Vsi možno pripodobit tvarom jednodielnych kalichov z okolia Košíc, ktoré majú ústie modelované do štyroch prečnievajúcich lalokov (Bánesz 1970, 326, obr. 2: 2; Šiška 1972, 136, tab. VIII: 4, 9). Z dvojdielneho kalicha by mohol pochádzat’ jeden črep z objektu 2, ktorý nápadne pripomína deliacu priečku. Jeho rozmery naznačujú, že bol súčastou nádoby stredne vel'kých rozmerov (tab. VII: 3). V hrnčiarstve skupiny Lažňany máme s istotou doložený len jeden fragment takmer z polovice zachovaného dvojdielneho kalicha, ktorý pochádza zo sídliskovej jamy z Bidoviec (Hreha 2016, 100)․ Jedno, ale aj dvojdielne štvorhranné kalichy patria k typickým keramickým formám kultúry Hunyadihalom (Kalicz 1980, 45, obr. 2: 10; Patay P. 2005, 82, tab. 22: 1, 3; Patay R. 2004, obr. 2: 6-8).

\section{Delené nádoby}

Na výskyt nádob s vnútornou deliacou priečkou v hrnčiarskej produkcii sídliska poukazujú tri črepy z objektu 2. Jeden z nich, tak ako už bolo naznačené, svojím tvarom a rozmermi môže pripomínat deliacu priečku z dvojdielneho kalicha (tab. VII: 3). Dalšie dva črepy v porovnaní s ním majú priečku omnoho nižšiu (tab. VII: 1, 2). Nádoby, z ktorých zmienené črepy pochádzajú, boli zhodne vyrobené z vel'mi jemne plavenej hliny a svojou hrúbkou sa jednoznačne radia $\mathrm{k}$ tenkostennej keramike. Pri vyhladávaní analógii k črepom 1 a 2 z tabul'ky VII sme v hrnčiarstve skupiny Lažňany nenašli žiadnu zhodu. Alternatívnu podobu k nim môžu vel'mi neurčito naznačovat iba fragmenty delených šálok kultúry Hunyadihalom, ktoré boli na dne predelované menšími priečkami na viacero miestach (Patay R. 2005, tab. 33: 1, 2, 5).

\section{Pokrievky}

Z objektu 1 pochádza zlomok plochej pokrievky naznačeného diskovitého tvaru s plastickým výčnelkom (tab. VI: 3). Druhý nález predstavuje nezdobená pokrievka kónického tvaru z objektu 2 (tab. VI: 13). Keramické nálezy tohto typu sa na lokalitách skupiny Lažňany objavujú len vel’mi sporadicky a pravdepodobne súvisia s jej starším vývojom (Šiška 1972, 137).

Odhliadnuc od nálezov z Dulovej Vsi sme z lažnianskych sídlisk donedávna evidovali iba jeden exemplár pokrievky z Ruskej. Pôvodne mala diskovitý tvar a jej súčastou bolo minimálne jedno uško situované na hrane plochého okraja (Horváthová/Gačková 2019, 240, tab. I: 1). Z preskúmaných hrobov je obdobne známy iba jeden nález pokrievky zo Šebastoviec. Má kuželovitý tvar a ulomenú rukovät (Šiška 1972, tab. VI: 9). V príbuznom prostredí kultúry Hunyadihalom sa tento typ keramiky objavuje omnoho častejšie (Hódmezővásárhely - Bognár-Kutzián 1969, obr. 5a, 5b; Tiszalúc - Patay P. 2005, 88, tab. 26; 28: $1-8 ; 30: 1-3,5)$.

\section{Atypický keramický fragment}

Z objektu 1 pochádza fragment keramiky pozdĺžneho tvaru s väčším otvorom na dne a s ulomenou dutou nôžkou (tab. VII: 4). Jeho výrazne otvorené dno naznačuje, že predmet sa pravdepodobne nepoužíval vo význame bežnej nádoby. Musel mat̉ inú bližšie neznámu funkciu. Uvažovat o ňom ako o fragmente oltárika alebo svietnika sa nám vzhladom na jeho tvar a chýbajúce stopy po pôsobení

\footnotetext{
Nepublikovaný nálezový súbor.
} 
ohňa nezdá pravdepodobné. ${ }^{8} \mathrm{~V}$ hrobe 23 zo Šebastoviec je síce známa misovitá nádoba oválneho (resp. vaničkovitého) tvaru, ale s plným dnom a bez dutej nôžky (Šiška 1972, tab. VII: 9). Z toho istého pohrebiska poznáme aj misku na nízkej nôžke a zlomky dvoch d’alších. Všetky spomínané nálezy boli uložené v hroboch zo staršej fázy pochovávania (Šiška 1972, 134).

Zlomky nádob na dutých nôžkach vieme opät dohladat’ v kultúre Hunyadihalom (Patay R. 2005, 84-86, tab. 23; 24: 1-7). Analogické tvary keramiky oválnej formy sa objavujú aj na pohrebiskách lubelsko-wołyńskej kultúry, v jej klasickej (II) a mladšej fáze (IIIa). Súčastou jednej z odtial prezentovaných nádob je aj dutá nôžka (Strzyżów 2A, hrob 4, Zakościelna 2006, obr. 3: 9, 14; Złota, Grodzisko II, hroby 101/1930, 122/1930; Zakościelna/Matraszek 2007, 414, 415, obr. 8: 21; 13: 10).

\section{Nevyobrazené ojedinelé zlomky keramiky}

Vo výplni objektu 1 sa vyskytol drobný črep z časti zaobleného tela tenkostennej nádoby, na ktorom sa nachádzajú dva malé otvory (jeden celý a druhý naznačený). Črep má výrazne korodované steny a na jeho vnútornej strane sa nachádza nápadne čierny povrch (vrecko 028/2013). Ak by sme sa stotožnili s názorom, že tento fragment by mohol súvisiet’ s nádobou vo funkcii cedidla bol by to jediný prípad výskytu keramiky tohto typu v doteraz známych nálezových súboroch skupiny Lažňany. Vzhladom na nedostatočne zachované rozmery nálezu považujeme jeho kategorické zaradenie ku konkrétnemu typu keramiky za neisté. ${ }^{9}$

Tvarovo definovaným, no kultúrne spochybnitel’ným nálezom z objektu 1 je aj úlomok z rozhrania hrdla a tela džbánu s častou zachovaného pásikového ucha (vrecko 0009/2012). Na základe makroskopického posúdenia zloženia keramickej hmoty a jej výpalu sa uvedený črep nijako neodlišuje od ostatnej analyzovanej keramiky. $\mathrm{V}$ doposial' objavených nálezových súboroch skupiny Lažňany sa džbány ${ }^{10}$ nevyskytli. Ich produkcia sa na sledovanom území rozvinula až po vyznení hrnčiarskych tradícií kultúr polgárskeho komplexu, v ére osídlenia badenskej kultúry a v dobe bronzovej.

\section{Výzdoba nádob}

Výzdoba keramiky je nevýrazná a vyskytuje sa len v minimálnej miere. Nachádza sa na okrajoch a na vonkajšom povrchu tiel zachovaných fragmentov, vrátane výzdoby úch a plochy pod nimi.

Niektoré zlomky z tvarov nádob bez hrdla boli zdobené vhíbenými jamkami alebo zásekmi situovanými priamo na hranu okraja (tab. I: 5, 6; II: 6; IV: 1-4; V: 1). Dekoratívny význam mal aj spôsob úpravy hornej časti tela štvorhranných kalichov, ktorých ústie bolo zvyčajne modelované do štyroch prečnievajúcich lalokov (tab. V: 4; VI: 1, 2). Z d’alších plastických výzdobných prvkov sme zaznamenali dutú, z vnútornej strany vytlačenú vypuklinu (tab. V: 3), malé zaoblené výčnelky (tab. I: 2; V: 7, 8), ale aj viac alebo menej masívne tupé výčnelky (tab. IV: 6; VI: 6). Hrubšie uchá mali člnkovitý tvar (tab. V: 12) a v nálezovom súbore nechýba ani typický nález ucha typu Scheibenhenkel (tab. V: 11) ${ }^{11}$.

Mimo plastickej výzdoby sa na povrchu niektorých fragmentov objavila tenká plytká drážka, ktorá zvyčajne oddel'ovala hrdlo od tela nádoby (tab. I: 1, 2; V: 3, 6). Na jednom z črepov bolo možné rozlíšit aj velmi slabo zachované pozdížne jamky, ktoré pôvodne zvýrazňovali predel medzi hrdlom a telom (tab. I: 4). Rozpoznané bolo aj zdrsnenie vonkajšieho a vnútorného povrchu tzv. slamovaním (objekt 1, vrecko 032/2013).

8 Zlomok pravouhlého hlineného oltárika vo funkcii svietnika s polgul’ovitým výčnelkom na zachovanej časti dna bol spolu s ostatnými nálezmi objavený na výšinnom sídlisku Nad Baňou v Hrčeli. Spája sa s horizontom osídlenia neskoroneolitickej skupiny Tiszapolgár-Csőszhalom-Oborín (Horváthová/Hreha 2015, 67, tab. VII: 6). Analógie k uvedenému typu keramiky nachádzame na viacerých lokalitách lengyelskej kultúry na Slovensku (Žlkovce), Morave, v Mad’arsku, Rakúsku a Nemecku (Bánffy 1997; Pavúk 1998).

9 V prostredí kultúry Hunyadihalom cedidlá obdobne nepatria k častým keramickým nálezom (Patay P. 2005, 85; tab. 24: 10).

10 Podobne ako aj cedidlá.

11 Charakteristický dekór spájaný s uchami typu Scheibenhenkel sa všeobecne vyskytoval na keramike viacerých eneolitických kultúr a kultúrnych skupín Bodrogkeresztúr B/Vajska/Lažňany/Hunyadihalom, taktiež v protobolerázskom stupni bolerázskej skupiny, v kontextoch Galatin a Sălcuța IV, čo možno chápat ako jeden z fenoménov vtedajšej doby dokazujúci nadregionálne vztahy spoločenstiev Karpatskej kotliny a Balkánu (Kalicz/Horváth 2010, 424, 425; Zalai-Gaál 2016, 12). Velmi zriedkavý je aj v mladších podunajských skupinách severne od Karpát. Z nich sa objavuje v najmladšej fáze skupiny Wyciąże-Złotniki (Czekaj-Zastawny/Przybyła 2012, 187, obr. 53: 2, 3; 54: 1, 2; Kaczanowska 1986, obr. 4; 5) a v lubelsko-wołyńskej kultúre (Kamieńska/Kozłowski 1990, obr. 31: 1, 4; Wilk 2016, obr. 7: C). 
V analyzovanom keramickom súbore absentuje rytá výzdoba (typická pre bodrogkeresztúrsku kultúru), barbotino, brázdený vpich (furchenstich), aplikovaná zoomorfná plastika v podobe štylizovaných zvieracích hlavičiek, ako aj malovanie stien, resp. účelová úprava povrchu čiernym náterom.

Ako cudzie výzdobné prvky na keramike skupiny Lažňany hodnotíme plastickú úpravu okrajov dvoch nádob bez hrdla v podobe solitérneho hrotitého a jazykovitého výčnelku (tab. II: 5; V: 10), ale aj pozdĺžny tupý výčnelok (tab. IV: 6) a malé polgulovité výčnelky (tab. V: 8).

\section{Hlinené predmety}

Z drobných predmetov vyrobených z hliny sa vo výplni objektu 1 nachádzali zlomky dvoch praslenov kuželovitého tvaru (tab. III: 5, 6) ${ }^{12}$, fragment predmetu neznámeho účelu (tab. III: 7) a jedna zoomorfná plastika, ktorú vzhladom na jej výskyt v sprievode nálezov skupiny Lažňany hodnotíme ako unikátny, ale cudzí element (tab. III: 1).

Zobrazuje štvornohé zviera s primerane dlhým, v hornej časti zúženým trupom a výraznejšie modelovanými zadnými končatinami. Spodobenie tela plastiky, bez zachovanej hlavy vrátane čiastočne poškodenej zadnej partie trupu, nám neumožňuje rozpoznat druh a ani pohlavie znázorňovaného zvierała. V najmladšom období polgárskeho kultúrneho horizontu evidujeme zhodné tematické prvky iba v podobe plasticky upravených štylizovaných hláv zvierat s naznačenými rohmi, ktoré zdobili telá nádob, alebo boli súčastou rukovätí hrncov a pokrievok (Patay P. 2005, tab. 55: 1-8; Šiška 1972, obr. 31: 1; 32: 6; 33: 1, 3). Do akej miery je správne tvrdenie, že tento typ výzdoby sa v sledovaných regiónoch východného Slovenska objavuje iba na lokalitách Košickej kotliny (Barca, Šebastovce) ukážu až budúce výskumy. Takmer identický plastický motív sa vyskytol aj na fragmente nádoby z Lúčok datovanom do prototiszapolgárskej fázy osídlenia (Šiška 1968, 76, obr. 6: 12; 1972, 138).

V chronologickom priereze materiálnej kultúry celého polgárskeho horizontu sa zoomorfný námet $\mathrm{v}$ akejkolvvek podobe zobrazoval len výnimočne. Pozorovaný bol na jeho počiatku v prototiszapolgárskej fáze osídlenia (Lúčky) a na jeho konci v horizonte pamiatok Hunyadihalom-Lažňany. Známa je aj štylizovaná kamenná plastika zvierata z klasickej fázy bodrogkeresztúrskej kultúry, pochádzajúca z rituálneho depozitu z lokality Pecica (Virag 2013, 180, 186, tab. VII: 5; VIII: 6a, 6b).

Solitérne zoomorfné plastiky sa začali zhotovovat až v nasledujúcich vývojových fázach stredného eneolitu s ich nástupom v bolerázskej skupine (Bondár 2015, 236, 241, tab. 55; Farkaš 2009, 7-16; Torma 1973, 486). V centrálnej a južnej časti stredného (Podpolanie, Gemer) a v severnej časti východného Slovenska (Spiš) sa ich výskyt spája s rozmachom osídlenia badenskej kultúry (Horváthová/Nevizánsky 2017, 73, 74, tab. XXIX: 14; XXXVII: 3; XLVI: 3; LIII: 6, 7; Malček 2013, 83-85, obr. 53; 2016, 111-113, obr. 79; NovotnálSoják 2013, 129, obr. 100-104; 105: 4-11; Soják 2001, 168, 175, obr. 2; 4: 1; 2007, 37, 41, obr. 45). Južne od tohto územia sú známe z lokalít Salgótarján (Korek 1968, tab. 12: 4; 13: 1-7), Ózd (Banner 1956, tab. 68: 3-6), Piliny (Patay P. 1999, 53, obr. 7) a Mezőkeresztes-Csincse (stručná zmienka pozri Nevizánsky 2009, 28). Analogicky blízke nálezy boli prezentované aj na náleziskách schneckenberskej kultúry (Prox 1941, tab. XI: 1; 3-8, 10), coțofenskej kultúry (Dudaş 1976, tab. 2: 6, 8; Popa 2009; Roman 1976, tab. 51: 13, 14; 52: 1-5) a tripol’skej kultúry (Peleščyšyn 1998, obr. 7: 4).

Úvahy o pôvode a význame plastiky z Dulovej Vsi, v kontexte pamiatok skupiny Lažňany, nechávame na širšiu odbornú diskusiu. Jej objavenie sa v blízkosti komunikačnej tepny stredného toku Torysy môže naznačovat' na pôsobenie viacerých priamych, ale aj sprostredkovaných kultúrnych prúdov. Jedným z nich by podla hypotézy S. Šišku $(1998,125,126)$ mohol byt๋ vplyv z prostredia bolerázskej skupiny ${ }^{13}$. Domnievame sa, že vzhl’adom na čast’ sprievodného materiálu vykazujúceho evidentne cudzie kultúrne znaky (t. j. zlomky keramiky s prvkami lubelsko-wołyńskej kultúry, čepelové škrabadlo z volynského pazúrika) možno genézu zvieracieho idolu odvodit najskôr od kontaktov zo súvekým obyvatel'stvom zakarpatských regiónov. Do pozornosti dávame niektoré plastiky tripol'skej kultúry z Bilcze Złote z jaskyne Werteba, ktoré vykazujú viaceré znaky takmer identické s plastikou z Dulovej Vsi (Țurcanu 2013, tab. 171: 1, 2). Zodpovedajú osídleniu jaskyne vo fáze CI a na začiatku fázy CII tripol'skej kultúry ${ }^{14}$. Na základe výsledkov štylisticko-typologických analýz, stratigrafických pozorovaní a výsledkov rádiouhlíkových datovaní bolo možné vývoj tripol’skej kultúry

\footnotetext{
12 Blízku analógiu k nim nachádzame aj na sídlisku v Tiszalúcu (Patay P. 2005, 108, 53: 3).

13 Za predpokladu, že skupina Lažňany bola v záverečnom časovom horizonte súčasná s jej počiatočným vývojom.

14 CI (koniec szypinieckej skupiny) a CII (skupina koszylowecka). Za konzultáciu d’akujem T. Tkachukovi.
} 
datovat' nasledovne: prelom etáp BII/CI okolo 3800 BC, prelom fáz CI/CII do 3600-3500 BC a záverečnú etapu CII do 2700 až 2600 BC. Prechodnú etapu CI/CII a začiatok etapy CII tripol'skej kultúry možno na časovej osi stotožnit’ s lubelsko-wołyńskou kultúrou vo fáze IIIb, skupinou Bajč-Retz, horizontom Hunyadihalom-Lažňany a juhovýchodnou skupinou kultúry lievikovitých pohárov (Gródek I, Bronocice II; Kadrow 2013, 16; Kadrow a i. 2003, 125). V lubelsko-wołyńskej kultúre sú figurálne plastiky známe vo vel’mi obmedzenom počte. Reprezentujú ich len dve malé antropomorfné figúrky z lokalít Złota (Podkowińska 1953, tab. XVIII: 1; XIX: 1, 2; XX: 2; Rauhut 1975, obr. 12; 13) a Las Stocki (Zakościelna 2002a, obr. 3: 2) a zatial jediná figúrka zvierata (Taras 1999, 76, 77, obr. 11). Vyzdvihnutá bola z kultúrnej vrstvy polykultúrnej lokality $3 \mathrm{v}$ Tyszowcach s doloženým osídlením a hrobmi lubelsko-wołyńskej kultúry. Podobne ako figúrka z Dulovej Vsi je bez zachovanej hlavy a nápadne pripomína plastiky „kráv“, ktoré sú známe z viacerých vyobrazení z lokalít tripol’skej kultúry z oblastí Volynia a Podolia (Konoplja 1997, obr. 8; Zakościelna 2002a, 66, 67, obr. 3: 3).

\section{Drobné predmety z kameňa}

Z objektu 1 pochádza čepelové škrabadlo s vrubmi a retušovanými stranami vyrobené z volynského pazúrika (tab. III: 2), obsidiánová čepiel'ka s náznakmi retušovania, fragment sekeromlatu z limonitovaného pieskovca (tab. VI: 4) a brúsik (?) so stopami vyhladenia. V objekte 2 sa vyskytli dve poškodené čepele vyrobené z obsidiánu (tab. III: 3, 4) a menšie kúsky suroviny z opálu (1 ks) a jurského pazúrika (2 ks).

Vymenované drobné predmety vyzdvihnuté z objektov skupiny Lažňany v Dulovej Vsi neprekvapujú nízkym počtom ani skladbou zastúpenej kamennej suroviny. Pôvodom zakarpatský volynský pazúrik, z ložísk z väčšej časti tiahnucich sa pozdĺž Dnesta a Prutu, mal pre rozvoj starších vývojových fáz polgárskych kultúr mimoriadny význam. Príkladom jeho vel'kého dopytu v spoločnosti tiszapolgárskej kultúry je pohrebisko vo Velkých Raškovciach, kde z celkového množstva štiepanej industrie tvoril až $90 \%$, pričom domáca obsidiánová industria mala len $8 \%$ zastúpenie (Vizdal 1977, 113). Analýza štiepenej industrie vo vybraných nálezových celkoch polgárskych kultúr (tiszapolgárskej, bodrogkeresztúrskej a skupiny Lažňany), ktorou sa zaoberala M. Kaczanowska (1980, 19-56), preukázala, že populácia bodrogkeresztúrskej kultúry z cudzích kamenných surovín preferovala volynský pazúrik, avšak nie v takom rozsahu, ako to možno sledovat’ v tiszapolgárskej kultúre. Naopak, v najmladšej etape polgárskeho vývoja, okrem zužitkovávania domácich surovinových zdrojov (rohovec, obsidián), možno sledovat jednoznačný pokles výskytu volynského pazúrika a vzostup používania pol'ských pazúrikov (najmä čokoládového, ale aj jurského a świeciechowskeho).

Predpokladá sa, že dôležitú úlohu v procese distribúcie kvalitnej kamennej suroviny do Karpatskej kotliny, v čase vývoja polgárskeho kultúrneho komplexu, zohrávala lubelsko-wołyńska kultúra. Najprv sprístupňovala prísun volynského pazúrika do osád tiszapolgárskej a bodrogkeresztúrskej kultúry a neskôr, pravdepodobne z dôvodu straty kontroly nad ložiskami vo Volyni ${ }^{15}$, presunula svoje aktivity na západ, kde časom prebrala kontrolu nad ložiskami čokoládového a jurského pazúrika (Kaczanowska 1980, 24, 30, 31, obr. 4; Zakościelna 2002b, 119) ${ }^{16}$. Ložiská świeciechowskeho pazúrika v tej dobe kontrolovala kultúra lievikovitých pohárov (Zakościelna 2002b, 119, 120).

15 Z dôvodu ich obsadenia tripol'skou kultúrou vo fáze C.

16 Vzdialenost' východného Slovenska k ložiskám pol’ských pazúrikov v priamej línii dosahuje k surovine čokoládového pazúrika približne $250 \mathrm{~km}$ a k surovine jurského pazúrika asi $200 \mathrm{~km}$. O čosi bližšie sa nachádzajú ložiská volynského pazúrika - asi 150 až 170 km (Kaczanowska 1980, 44). 


\section{KATALÓG}

\section{Opis nálezových situácií a nálezov}

\section{Objekt 1}

Jama väčších rozmerov nepravidelne oválneho pôdorysu. Na dvoch miestach bola porušená výkopmi pre inžinierske siete, ktoré ju pretínali v južnej časti v smere V - Z a vo východnej časti v smere S - J. Steny jamy klesali mierne šikmo až kolmo k plytkému, miestami takmer rovnému dnu. Výplň tvorila hlinitá vrstva čiernosivej farby s prímesou drobných kúskov mazanice a uhlíkov. Pod ňou sa na menšej ploche nachádzala ílovito-hlinitá vrstva sivej farby s obsahom popola. V severozápadnej časti sa na jej dne objavil pôdorys d’alšej súdobej jamy menších rozmerov (objekt 1A).

Celkové rozmery objektu: 8,75 x 7,40 m; hí. 0,48 m (obr. 4: 1).

Nálezy: zlomky keramiky, drobné predmety z hliny (zoomorfná plastika, fragmenty hlinených praslenov, fragment hlineného predmetu neznámeho účelu), kamenná industria (4 ks), drobné kúsky mazanice (12ks).

\section{Opis vyobrazených nálezov}

- Tenkostenný črep z okraja nádoby. Rozhranie hrdla a tela vymedzuje plytká obvodová ryha. Povrch hladený. Makroskopický opis materiálu: jemne plavená hlina s drobnými kúskami šamotu. Farba: terakotovohnedá. Priemer ústia kresbovej rekonštrukcie nádoby $12 \mathrm{~cm}$. Inv. č. 024 (tab. I: 1).

- Tenkostenný črep z misy, ktorá mala odsadené hrdlo a zaoblené telo. Na maximálnej vydutine črepu sa zachoval čiastočne poškodený plastický výčnelok. Makroskopický opis materiálu: jemne plavená hlina. Farba: terakotovohnedá. Priemer ústia kresbovej rekonštrukcie nádoby 13 cm. Inv. č. 024 (tab. I: 2).

- Črep z misy s rovným odsadeným hrdlom a mierne zaobleným telom. Makroskopický opis materiálu: jemne plavená hlina. Farba: terakotovohnedá. Priemer ústia po kresbovej rekonštrukcii nádoby 20-22 cm. Inv. č. 61/2013 (tab. I: 3).

- Črep z misy s rovným odsadeným hrdlom a mierne zaobleným telom. Na rozhraní hrdla a tela sa nachádzajú štyri slabo viditel’né jamky. Makroskopický opis materiálu: jemne plavená hlina. Farba: terakotovohnedá. Priemer ústia po kresbovej rekonštrukcii nádoby $22 \mathrm{~cm}$. Inv. č. 030 (tab. I: 4).

- Črep z okraja neprofilovanej misovitej, prípadne hrncovitej nádoby. Na vonkajšej strane povrchu sa nachádza viacero neusporiadaných tenkých rýh. Makroskopický opis materiálu: jemne plavená hlina s drobnými kúskami šamotu. Farba: terakotovohnedá. Priemer ústia po kresbovej rekonštrukcii nádoby 26 cm. Inv. č. 029 (tab. I: 5).

- Črep z misy s mierne vtiahnutým okrajom zdobeným na celom obvode šikmými jamkami. Makroskopický opis materiálu: jemne plavená hlina. Farba: terakotovohnedá. Priemer ústia po kresbovej rekonštrukcii nádoby $30 \mathrm{~cm}$. Inv. č. 0010B/2012 (tab. I: 6).

- Črep z neprofilovanej misovitej nádoby bez hrdla. Bez výzdoby. Makroskopický opis materiálu: jemne plavená hlina. Farba: sivohnedá. Inv. č. 033/2012 (tab. IV: 2).

- Črep z nádoby s okrajom zdobeným jamkami. Makroskopický opis materiálu: jemne plavená hlina. Farba: terakotovohnedá. Inv. č. 021 (tab. IV: 3).

- Črep zo stredne hrubostennej misy. Na jeho vonkajšej strane sa nachádza slabšie viditelné zoskupenie troch zvislých kanelúr. V hornej časti okraja sú vhĺbené plytké jamky. Makroskopický opis materiálu: jemne plavená hlina. Farba: terakotovohnedá. Inv. č. 034 (tab. V: 1).

- Črep zo šálky jemne esovitého profilu. Má hrubší, mierne do vonkajšej strany vyhnutý a hladko zarovnaný okraj. Pod ním sa nachádza výraznejšie vyhladená plocha. Bez výzdoby. Makroskopický opis materiálu: jemne plavená tvrdo vypálená hlina. Farba: sivohnedá (tab. V: 2).

- Črep z misy s takmer rovným odsadeným hrdlom a zaobleným telom. Na pleciach je zdobený vypuklinou vytlačenou z vnútornej strany steny. Na povrchu v mieste odsadenia hrdla od tela je výraznejšie vyhladený povrch. Pod ním sa zachovala čast’ pôvodnej vrstvy hlineného náteru. Makroskopický opis materiálu: jemne plavená hlina. Farba: terakotovohnedá. Inv. č. 028 (tab. V: 3).

- Črep z hornej časti nádoby hranatého tvaru s jednoduchým lalokovitým výčnelkom, ktorý pôvodne presahoval nad ústie nádoby. Makroskopický opis materiálu: jemne plavená hlina. Farba: terakotovohnedá. Zachovaná maximálna výška črepu 6 cm. Inv. č. 023 (tab. V: 4).

- C Crep z hrncovitej nádoby bez hrdla s vyhnutým okrajom zdobeným nesúmernými jamkami. Makroskopický opis materiálu: jemne plavená hlina. Farba: terakotovohnedá. Inv. č. 023 (tab. V: 5).

- Črep z časti hrdla a tela menšej amforovitej nádoby. Rozhranie hrdla a tela zvýrazňuje vyhladený povrch imitujúci žliabok. Na maximálnu vydutinu tela je situované malé ucho s vertikálnym otvorom. Makroskopický opis materiálu: jemne plavená hlina. Farba: terakotovohnedá. Inv. č. 0017 (tab. V: 6).

- Črep z tela nádoby s odlomeným pásikovým uchom. Nižšie pod ním je situovaný malý plastický výčnelok oválneho tvaru. Makroskopický opis materiálu: jemne plavená hlina. Farba: terakotovohnedá. Inv. č. 028 (tab. V: 7).

- Črep z rozhrania hrdla a tela amforovitej nádoby. Jeho súčastou je malé široké ucho pásikového tvaru. Makroskopický opis materiálu: jemne plavená hlina. Farba: terakotovohnedá. Inv. č. 034 (tab. V: 9).

- Črep z hornej časti misovitej nádoby. V hornej časti je zdobený lalokovitým výčnelkom presahujúcim nad okraj. Makroskopický opis materiálu: jemne plavená hlina. Farba: terakotovohnedá. Inv. č. 002 (tab. V: 10).

- Črep z tela hrubostennej pravdepodobne zásobnicovej nádoby s masívnym člnkovitým uchom. Makroskopický opis materiálu: jemne plavená hlina. Farba: terakotovohnedá. Inv. č. 009 (tab. V: 12). 
- Črep z tela stredne hrubostennej amforovitej nádoby. Na rozhranie hrdla a tela je situované ucho pásikového tvaru. Makroskopický opis materiálu: jemne plavená hlina. Farba: sivohnedá. Inv. č. 009 (tab. V: 13).

- Fragment plochej pokrievky s ulomeným plastickým výčnelkom. Povrch hladený. Makroskopický opis materiálu: jemne plavená hlina. Farba: hnedosivá. Inv. č. 032 (tab. VI: 3).

- Masívny plastický výčnelok. Povrch hladený. Makroskopický opis materiálu: jemne plavená hlina. Farba: terakotovohnedá. Rozmery: dížka 4,4 cm. Inv. č. 028 (tab. VI: 6).

- Fragment z dna nádoby. Bez výzdoby. Povrch hladený. Makroskopický opis materiálu: jemne plavená hlina. Farba: terakotovohnedá. Inv. č. 029 (tab. VI: 11).

- Črep z časti dna a tela nádoby hranatého tvaru. Bez výzdoby. Povrch hladený. Makroskopický opis materiálu: jemne plavená hlina. Farba: terakotovohnedá. Rozmery: zachovaná výška 6 cm. Inv. č. 009 (tab. VI: 12).

- Fragment nádoby neznámej funkcie so zachovanou vrstvou povrchového hlineného náteru. Nádoba mala pôvodne pozdížny tvar, dutú nôžku a na jej dne sa nachádzal väčší otvor oválneho tvaru. Hrúbka stien $0,8-0,9$ cm. Bez výzdoby. Makroskopický opis materiálu: jemne plavená hlina. Farba: sivohnedá. Inv. č. 038/2013 (tab. VII: 4).

\section{Drobné predmety}

- Miniatúrna hlinená plastika štvornohého zvierata. Hlava sa nezachovala. Zadné končatiny má výraznejšie modelované ako predné. Makroskopický opis materiálu: jemne plavená hlina. Farba: svetlohnedá. Zachované rozmery: dížka $4 \mathrm{~cm}$, šírka prednej časti tela $1,1 \mathrm{~cm}$; šírka zadnej časti tela $2,2 \mathrm{~cm}$; šírka hornej časti tela $0,7 \mathrm{~cm}$; šírka dolnej časti tela 1,4 cm. Inv. č. 037 (tab. III: 1).

- Fragment hlineného praslena kuželovitého tvaru. Makroskopický opis materiálu: jemne plavená hlina. Farba: svetlohnedá. Zachované rozmery 6,9 x 7,4 cm. Inv. č. 022/13 (tab. III: 5).

- Fragment hlineného praslena kuželovitého tvaru. Makroskopický opis materiálu: jemne plavená hlina. Farba: svetlohnedá. Zachované rozmery 7,7 x 4 cm. Inv. č. 0009/2012 (tab. III: 6).

- Fragment hlineného predmetu neznámej funkcie, ktorý má na užšej nepoškodenej strane zaoblený tvar. Makroskopický opis materiálu: jemne plavená hlina. Farba: svetlohnedá. Zachované rozmery: 6,3 x 4,8-5,3 cm. Inv. č. 024/2013 (tab. III: 7).

- Čepelové škrabadlo s vrubmi s retušou na pravej a lavej strane. Surovina: volynský pazúrik. Inv. č. 0006 (tab. III: 2).

- Fragment sekeromlatu. Surovina: silno železité pieskovcové jadro s kôrou limonitu a tvrdého limonitovaného pieskovca s hrúbkou kôry 2 až 3 mm¹7. Zachované rozmery: výška: 3,7 cm; šírka 5,1cm. Inv. č. 0011 (tab. VI: 4).

- Brúsik (?) so stopami vyhladenia. Surovina: neznáma.

- Čepiel'ka s náznakmi retušovania. Surovina: obsidián.

\section{Objekt 1A}

Jama situovaná v severozápadnej časti objektu 1. Mala nepravidelne kruhový pôdorys, šikmo zvažujúce steny a zaoblené dno. Jej výplň od hora na dol tvorila hlina čiernosivej farby s prímesou mazanice a uhlíkov, ílovitá hlina sivej farby s obsahom popola a ílovitá hlina žltohnedej farby.

Celkové rozmery objektu: 1,40 x 1,60; hí. 1,16 m (obr. 4: 1).

Nálezy: zlomky keramiky a drobné kúsky mazanice $(7 \mathrm{ks})$.

\section{Opis vyobrazených nálezov}

- Črep z hrncovitej nádoby. Nádoba mala širšie ústie, rovné hrdlo a zaoblené telo, ktoré v mieste odsadenia po celom obvode vymedzuje plytký žliabok. Makroskopický opis materiálu: jemne plavená hlina. Farba: terakotovohnedá. Priemer ústia po kresbovej rekonštrukcii $18 \mathrm{~cm}$. Inv. č. 0014 (tab. II: 4).

- Črep z hornej časti širšej neprofilovanej misy. Z jej okraja smerom na hor vybieha zašpicatený plastický výčnelok. Makroskopický opis materiálu: jemne plavená hlina. Farba: terakotovohnedá. Priemer ústia po kresbovej rekonštrukcii 20 cm. Inv. č. 0014 (tab. II: 5).

- Črep z hornej časti širšej neprofilovanej misy. Bez výzdoby. Makroskopický opis materiálu: jemne plavená hlina. Farba: terakotovohnedá. Priemer ústia po kresbovej rekonštrukcii 24 cm. Inv. č. 0014 (tab. II: 6).

- Črep z okraja hrncovitej nádoby s tupým plastickým výčnelkom. Makroskopický opis materiálu: jemne plavená hlina. Farba: terakotovohnedá. Inv. č. 0014 (tab. IV: 5).

- Črep z rozhrania hrdla a tela profilovanej nádoby s tupým plastickým výčnelkom. Povrch hladený. Makroskopický opis materiálu: jemne plavená hlina. Farba: terakotovohnedá. Inv. č. 0014 (tab. IV: 6).

- Crep z hrdla a tela stredne hrubostennej nádoby. Mierne von vyhnuté hrdlo má odsadené od širšieho zaobleného tela. Bez výzdoby. Makroskopický opis materiálu: jemne plavená hlina. Farba: terakotovohnedá. Inv. č. 0014 (tab. IV: 9).

- Zlomok z hornej časti tela nádoby s člnkovitým uchom. Makroskopický opis materiálu: jemne plavená hlina. Farba: terakotovohnedá. Inv. č. 0014 (tab. IV: 10).

- Dva črepy z tela tenkostennej nádoby s dvojicou malých tupých plastických výčnelkov. Makroskopický opis materiálu: jemne plavená hlina. Farba: terakotovohnedá. Inv. č. 0014 (tab. V: 8).

17 Škrupinovitá kôra na fragmente sekeromlatu je výsledkom dlhodobého procesu „naimpregnovania“ pieskovca železitými zlúčeninami vyskytujúcimi sa bud’ priamo v pieskovci, alebo v prostredí, v ktorom sa nachádzal. Za odborné posúdenie suroviny, z ktorej bol pôvodne nástroj vyrobený, d’akujeme RNDr. J. Molnárovi. 
- Takmer úplne zachované dno s častou tela nádoby štvorhranného tvaru. Bez výzdoby. Na jednej časti povrchu sa zachovala vrstva pôvodného hlineného náteru. Makroskopický opis materiálu: jemne plavená hlina. Farba: hnedosivá. Rozmery: šírka dna 6,2 cm; maximálna výška zachovanej steny 4,5 cm; hrúbka steny 0,5 cm. Inv. č. 014 (tab. VI: 5).

\section{Objekt 2}

Jama väčších rozmerov nepravidelne oválneho pôdorysu. Porušená bola dvomi výkopmi pre inžinierske siete, ktoré ju pretínali v smere $\mathrm{V}$ - Z. Steny jamy klesali šikmo, v niektorých úsekoch kolmo, k rovnému, miestami aj zaoblenému dnu. V centrálnej časti jamy sa nachádzala menšia plytká jama s priemerom $1,90 \mathrm{~m}$, ktorej opis sa v nálezových listoch neuvádza. Jej dno nepresiahlo dno objektu 2. Výplň rozmernej jamy z väčšej časti tvorila hlinitá vrstva sivohnedej farby s obsahom mazanice a uhlíkov. Pozdíž jej stien sa vyskytovala ílovitá hlina žltohnedej farby. Tesne nad dnom sa na malej ploche nachádzala mastná hlina hnedosivej farby s prímesou mazanice a uhlíkov.

Celkové rozmery objektu: 7,80 x 7,62 m; hí. 0,80-1,10 m (obr. 4: 2).

Nálezy: zlomky keramiky, kamenná industria (3 ks), kamenná surovina (3 ks), drobné kúsky mazanice (12ks).

\section{Opis vyobrazených nálezov}

- Fragment prechodného typu šálky s jemne esovitým profilom. Bez výzdoby. Na vonkajšej strane povrchu sa zachovala tenká vrstva hlineného náteru tmavohnedej farby. Makroskopický opis materiálu: hlina s obsahom drobných drsných anorganických prímesí. Farba: svetlohnedá. Priemer ústia po kresbovej rekonštrukcii 8 cm. Inv. č. 056 (tab. II: 1).

- Fragment prechodného typu šálky s jemne esovitým profilom. Bez výzdoby. Má hladený povrch s náznakom leštenia. Makroskopický opis materiálu: hlina s obsahom jemných drsných anorganických prímesí. Tvrdší výpal. Farba: sivohnedá. Priemer ústia po kresbovej rekonštrukcii $10 \mathrm{~cm}$. Inv. č. 056 (tab. II: 2).

- Črep z misovitej nádoby. Má takmer rovné hrdlo a zaoblené telo, ktoré v mieste odsadenia po celom obvode vymedzuje plytký žliabok. Makroskopický opis materiálu: jemne plavená hlina. Farba: terakotovohnedá. Priemer ústia po kresbovej rekonštrukcii $18 \mathrm{~cm}$. Inv. č. 051 (tab. II: 3).

- Črep z hornej časti širokej tenkostennej nádoby. Na jeho okraji sa nachádza výzdoba v podobe vtlačených jamiek. Makroskopický opis materiálu: jemne plavená hlina. Farba: terakotovohnedá. Inv. č. 051 (tab. IV: 1).

- Črep z hornej časti stredne hrubostennej misovitej alebo hrncovitej nádoby. Na jeho okraji sa nachádza výzdoba v podobe vtlačených jamiek. Makroskopický opis materiálu: jemne plavená hlina. Farba: terakotovohnedá. Inv. č. 063/2012 (tab. IV: 4).

- Tri črepy z hornej časti hrncovitých nádoby s malým uchom presahujúcim ich pôvodný okraj. Makroskopický opis materiálu: jemne plavená hlina. Farba: terakotovohnedá. Vrecká 043, 068 (tab. IV: 7, 8, 12).

- Črep z tela nádoby. Na jeho povrchu sa nachádzajú zvislé pseudokanelúry. Makroskopický opis materiálu: neplavená hlina. Tvrdý výpal. Farba: terakotovohnedá. Inv. č. 040/2013 (tab. IV: 11).

- Črep z hrncovitej nádoby s nižším odsadeným hrdlom a baňatým telom. Z hrdla nad okraj presahuje široké pásikové ucho. Bez výzdoby. Makroskopický opis materiálu: jemne plavená hlina. Farba: terakotovohnedá. Inv. č. 056 (tab. IV: 13).

- Črep z hrubostennej hrncovitej nádoby. Z hrdla nad okraj presahuje široké pásikové ucho typu Scheibenhenkel s lalokovito formovaným výčnelkom. Makroskopický opis materiálu: jemne plavená hlina. Farba: terakotovohnedá. Inv. č. 043/2013 (tab. V: 11).

- Črep z hornej časti nádoby naznačeného hranatého tvaru s jednoduchým lalokovitým výčnelkom, ktorý pôvodne presahoval nad ústie nádoby. Bez inej výzdoby. Makroskopický opis materiálu: jemne plavená hlina. Farba: terakotovohnedá. Zachovaná maximálna výška črepu 7,5 cm. Inv. č. 055 (tab. VI: 1).

- Črep z hornej časti nádoby naznačeného hranatého tvaru s jednoduchým lalokovitým výčnelkom, ktorý pôvodne presahoval nad ústie nádoby. Bez inej výzdoby. Makroskopický opis materiálu: jemne plavená hlina. Farba: terakotovohnedá. Zachovaná maximálna výška črepu 4,1cm. Inv. č. 066 (tab. VI: 2).

- Črep pochádzajúci z tela hranatého kalicha. Na jeho povrchu sa zachovalo malé ucho s horizontálnym otvorom. Makroskopický opis materiálu: jemne plavená hlina. Farba: terakotovohnedá. Inv. č. 055 (tab. VI: 7).

- Črep zo spodnej časti nádoby naznačeného hranatého tvaru. Na zalomenej strane stien je naznačená plastická lišta. Makroskopický opis materiálu: jemne plavená hlina. Farba: hnedá. Rozmery: zachovaná výška steny $2,3 \mathrm{~cm}$. Inv. č. 051 (tab. VI: 8).

- Spodná čast’ nádoby naznačeného hranatého tvaru zachovaná v podobe dvoch fragmentov. Bez výzdoby. Na vnútornej a vonkajšej strane črepov je rozpoznatel’ná tenká vrstva hlineného náteru tmavohnedej farby. Makroskopický opis materiálu: jemne plavená hlina. Farba: sivohnedá. Inv. č. 047 (tab. VI: 9).

- Črep z dolnej časti nádoby naznačeného hranatého tvaru. Bez výzdoby. Makroskopický opis materiálu: jemne plavená hlina. Farba: sivohnedá. Inv. č. 051 (tab. VI: 10).

- Fragment pokrievky s kónickými stenami, ktoré sú pri okraji výrazne stenčené. Bez výzdoby. Makroskopický opis materiálu: jemne plavená hlina. Farba: sivohnedá. Rozmery: výška 5,5 cm. Inv. č. 053 (tab. VI: 13).

- Črep z nádoby s častou zachovanej deliacej priečky. Bez výzdoby Makroskopický opis materiálu: jemne plavená hlina. Farba: sivohnedá. Inv. č. 068 (tab. VII: 1).

- Črep z nádoby s častou zachovanej deliacej priečky, na ktorej sa zachovala čast’ pôvodného hlineného náteru. Makroskopický opis materiálu: jemne plavená hlina. Farba: sivohnedá. Inv. č. bez označenia (tab. VII: 2).

- Črep z deliacej priečky stredne vel'kej nádoby. Bez výzdoby. Makroskopický opis materiálu: jemne plavená hlina. Farba: sivohnedá. Inv. č. 040 (tab. VII: 3). 
Drobné predmety

- Poškodená čepel'. Surovina: obsidián. Inv. č. 041 (tab. III: 3).

- Zlomená čepel' s úžitkovou retušou na oboch stranách. Surovina: obsidián. Inv. č. 041 (tab. III: 4).

- Surovina: opál.

- Surovina: jurský pazúrik (2 ks).

\section{ZÁVER}

Posudzované nálezy z Dulovej Vsi reprezentujú najmladší horizont osídlenia polgárskeho kultúrneho komplexu. Majú jednoznačne synkretickú povahu so znakmi prienikov viacerých kultúr. Z hrnčiarskych výrobkov prevažujú identifikačné črty skupiny Lažňany, ktoré sú v mnohom porovnatelné s keramikou kultúry Hunyadihalom (misy s vel’mi zaobleným telom a výrazne odsadeným hrdlom cylindrického alebo mierne lievikovitého tvaru, misy oválneho resp. vaničkovitého tvaru, hrnce s naznačeným hrdlom a s dvoma robustnejšími uchami pri okraji, štvorhranné tvary nádob v podobe kalichov a pokrievky; z dekoratívnych prvkov sú to okraje nádob zdobené jamkami alebo zásekmi, z vnútornej strany stien vytlačené vypukliny, člnkovité tvary úch a uchá typu Scheibenhenkel).

Viaceré z vymenovaných znakov sa objavujú aj na keramike najmladšej fázy skupiny Wyciąże-Złotniki a lubelsko-wołyńskej kultúry (fáza III). Ako cudzie elementy v posudzovanom súbore sa zdajú byt fragmenty tenkostenných šálok s esovitou profiláciou, nízkym hrdlom a baňatým telom (tab. II: 1, 2), hrotitý výčnelok presahujúci okraj nádoby (tab. II: 5), jazykovitý výčnelok vychádzajúci z okraja (tab. V: 10), pozdížny tupý výčnelok (tab. IV: 6) a malé polgulovité výčnelky (tab. V: 8). Domnievame sa, že zmienené atribúty vykazujú značnú podobnost’ s keramikou lubelsko-wołyńskej kultúry, ktorá predstavovala najvzdialenejšiu frakciu polgárskeho vplyvu severne od Karpát (Czekaj-Zastawny/Przybyła 2012, obr. 66: 1, 2, 3; 72: 10; 73: 3; Kruk/ Milisauskas 1985, 10). Ďalším dôkazom o heterogenite archeologického materiálu z Dulovej Vsi je aj objav zoomorfnej plastiky, ktorá je v nálezoch skupiny Lažňany práve tak ojedinelá, ako je ojedinelá aj zvieracia plastika lubelsko-wołyńskej kultúry vyzdvihnutá z lokality Tiszowce (východné Pol’sko). Obe figúrky nápadne pripomínajú zoomorfné idoly z viacerých vyobrazení tripol'skej kultúry. Odkaz vplyvu z tohto kultúrneho prostredia je zretelný nielen $\mathrm{v}$ kamennej industrii, ale dá sa výnimočne rozpoznat aj na keramike z lokalít Hołyszów, Strzyżów a Košice-Barca (Chmielewski 2008, 86; Podkowińska 1960, 50; Šiška 1972, 155).

Rozsah vplyvu, ako aj samotný prienik časti polgárskeho obyvatel'stva smerom na sever (hlavne do oblasti Malopol'ska) bol dlhodobo spájaný s tiszapolgárskou a predovšetkým s bodrogkeresztúrskou kultúrou (Kozłowski 1971; 2006; Zakościelna 2010). Vyplynulo to jednak z početných nálezov pazúrikovej industrie vyskytujúcej sa na lokalitách vo vnútrozemí Karpát, na druhej strane sa severne od tohto územia čoraz častejšie objavovali medené predmety vnútrokarpatskej proveniencie. Vysokú mieru mobility bodrogkeresztúrskej kultúry možno postrehnút aj v skupine Wyciąże-Złotniki (Czekaj-Zastawny/Kabaciński/Terberger 2011; Grabowska/Zastawny 2011; Kozłowski 2006, 56). Nálezy jantárových perál z pohrebiska v Lažňanoch a zlomky bodrogkeresztúrskej keramiky na lokalite Dąbki (severné Pol’sko) naznačujú aj možnosti vzdialenejších kontaktov polgárskych populácií až s pobaltskými regiónmi (Czekaj-Zastawny/Kabaciński/Terberger 2011; Šiška 1972, 145; Terberger/Kabaciński 2010).

Výsledky novodobých výskumov nás však čoraz viac utvrdzujú v názore, že obyvatel'stvo najmladšej fázy polgárskeho kultúrneho komplexu nemalo menší podiel na pokračovaní šírenia eneolitických kultúrnych vzorov z Karpatskej kotliny smerom na sever. Excelentný príklad vzájomného kultúrneho pôsobenia horizontu Hunyadihalom-Lažňany a lubelsko-wołyńskej kultúry predstavujú dva nedávno zverejnené birituálne hroby z polohy 2, na pohrebisku v Książnicach (hroby 7 a 14). Vo výbave kostrového hrobu 7 vidíme takmer ukážkový vzor prelínania sa (resp. prevažovania) mladopolgárskych signifikantných prvkov s kultúrno identifikačnými znakmi lubelsko-wołyńskej kultúry. V hrobe a jeho okolí sa našla aj bohatá súprava šperkov vrátane piatich medených artefaktov. Rádiouhlíkové datovanie osteologického materiálu z hrobu určuje jeho vek na 4050-3940 BC (Wilk 2016, 13, obr. 6; 7; 9). Výnimočnost’ druhého hrobu 14 možno vidiet’ $\mathrm{v}$ tom, že je prvým kremačným eneolitickým pohrebom $\mathrm{v}$ juhovýchodnom Pol'sku, ktorý bol objavený na pohrebisku lubelsko-wołyńskej kultúry (Wilk/Szczepanek 2017). Môže to naznačovał', že vplyv horizontu Hunyadihalom-Lažňany bol natol'ko intenzívny, že v cudzom kultúrnom prostredí zanechal stopu v občasnom tolerovaní odchýlok zaužívaného pohrebného rítu. Na základe najnovších úprav rádiokarbónovej chronológie by sa vzájomné interakcie lubelsko-wołyńskej kultúry, skupiny Lažňany a kultúry Hunyadihalom, mali odohrávat' v období medzi rokmi 4 000/3950-3800/3750 cal. BC (Brummack 2015, 13; Wilk 2016). Novoprijaté rádiouhlíkové dáta spresňujú aj trvanie skupiny Wyciąże-Złotniki a ohraničujú ho rokmi 4200-3800/3750 BC (Grabowska/Zastawny 2011, 134; Nowak 2014, 250). 


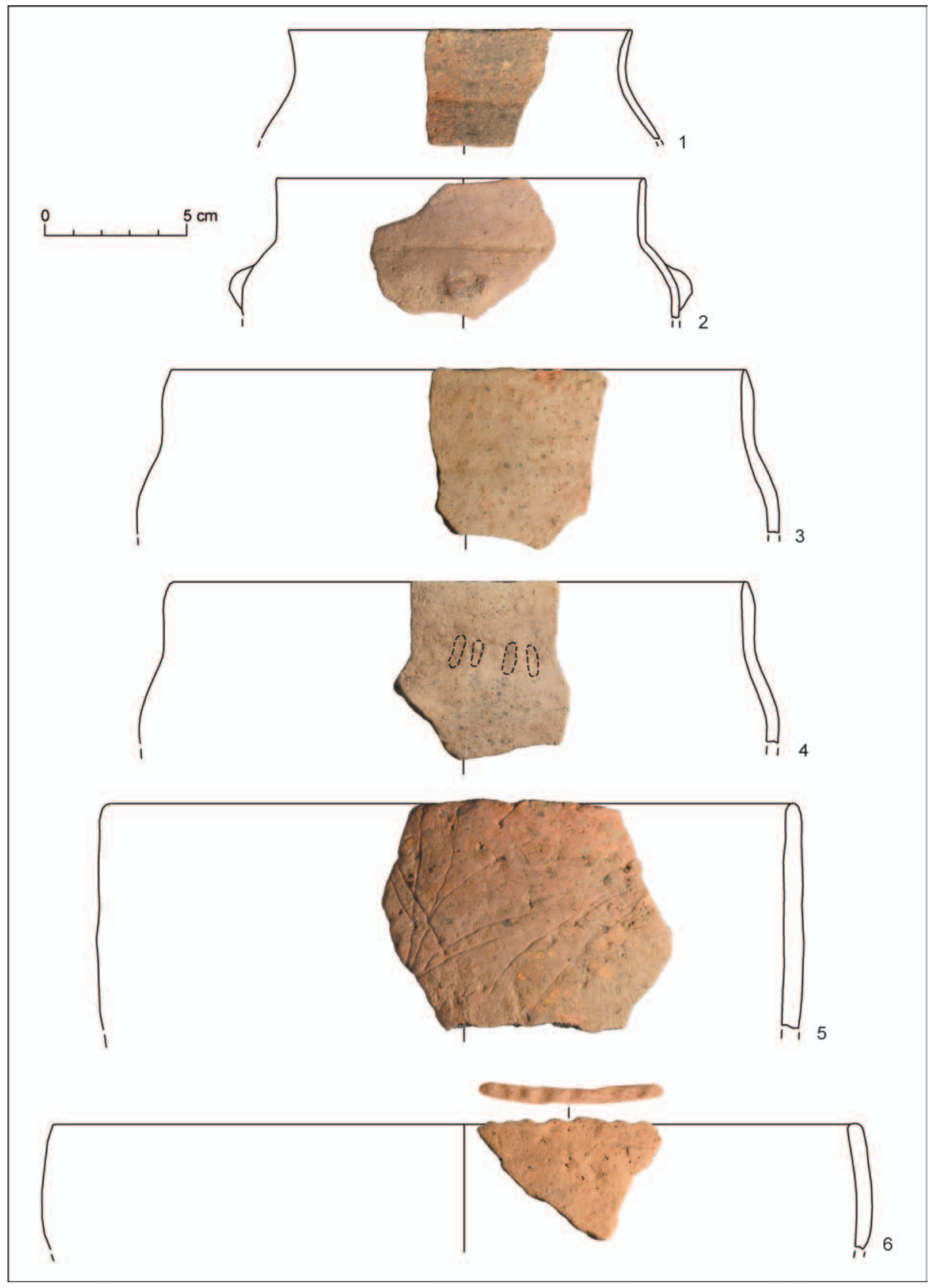

Tab. I. Dulova Ves-Čergov II. Výber nálezov z objektu 1. Foto A. Marková. 

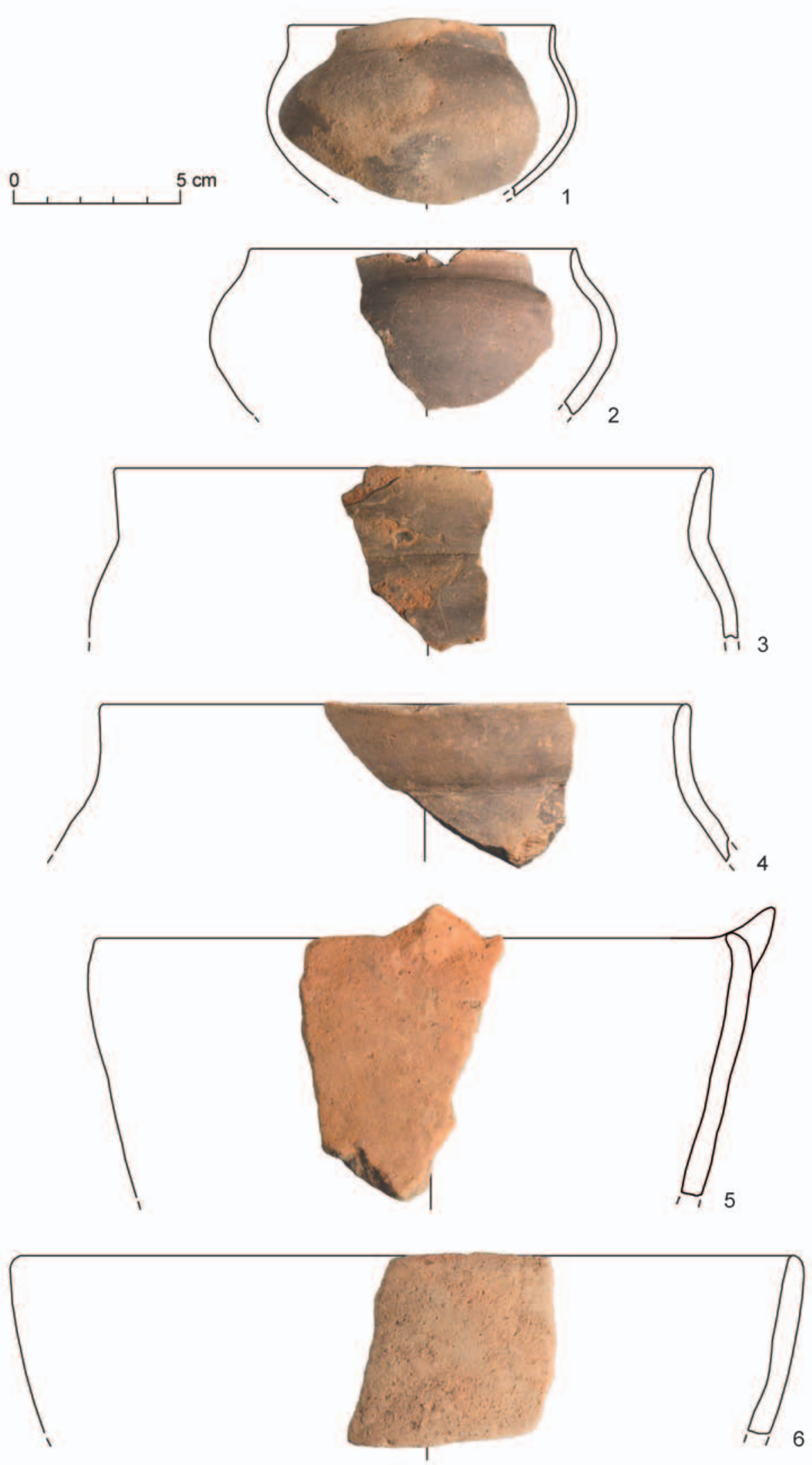

Tab. II. Dulova Ves-Čergov II. 1-3 - výber nálezov z objektu 2; 4-6 - výber nálezov z objektu 1A. Foto A. Marková. 


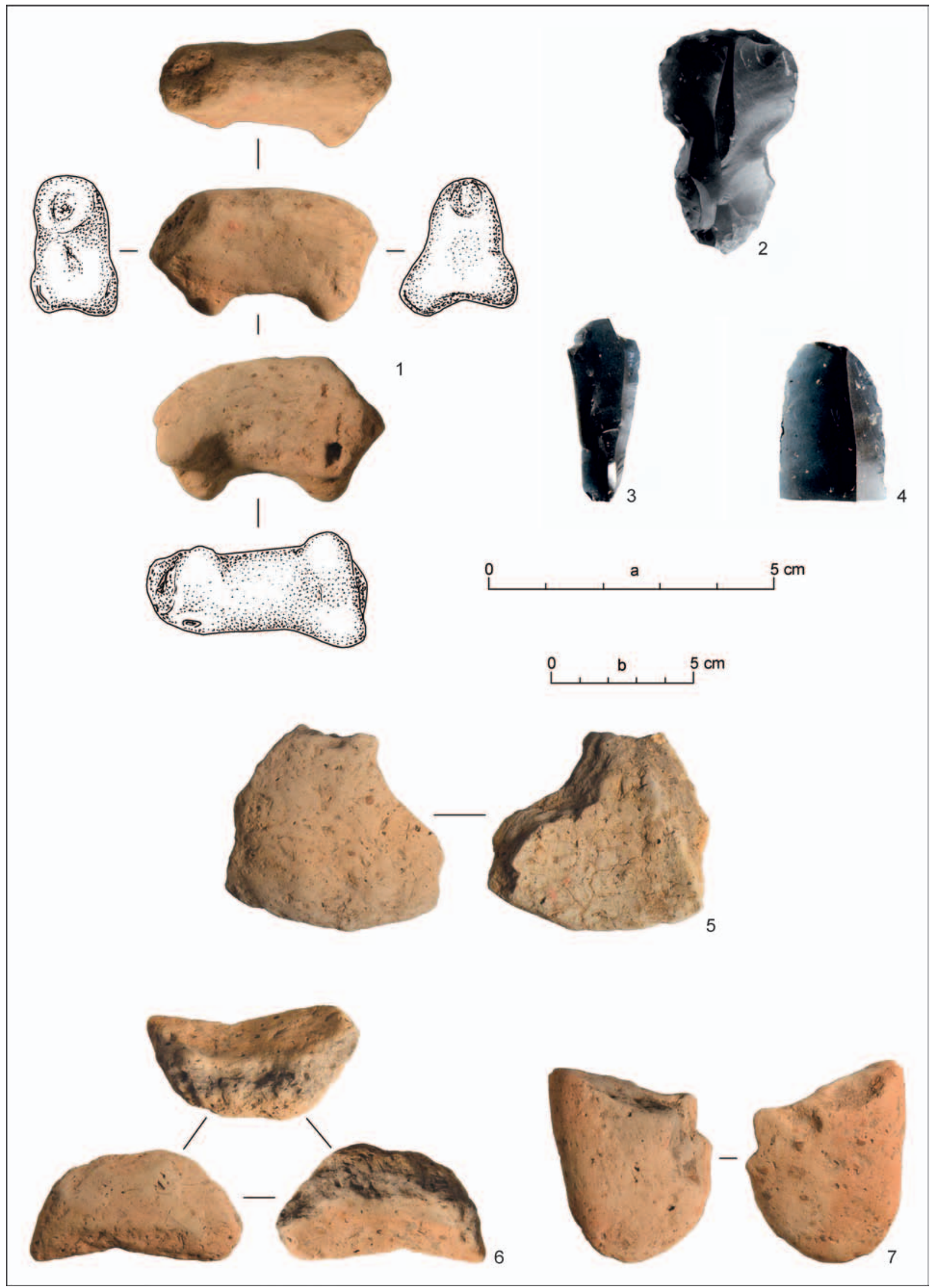

Tab. III. Dulova Ves-Čergov II. 1, 2, 5-7 - výber nálezov z objektu 1; 3, 4 - výber nálezov z objektu 2. Mierka: a - 1-4; b-5-7. Foto A. Marková, kresba P. Šimčík. 


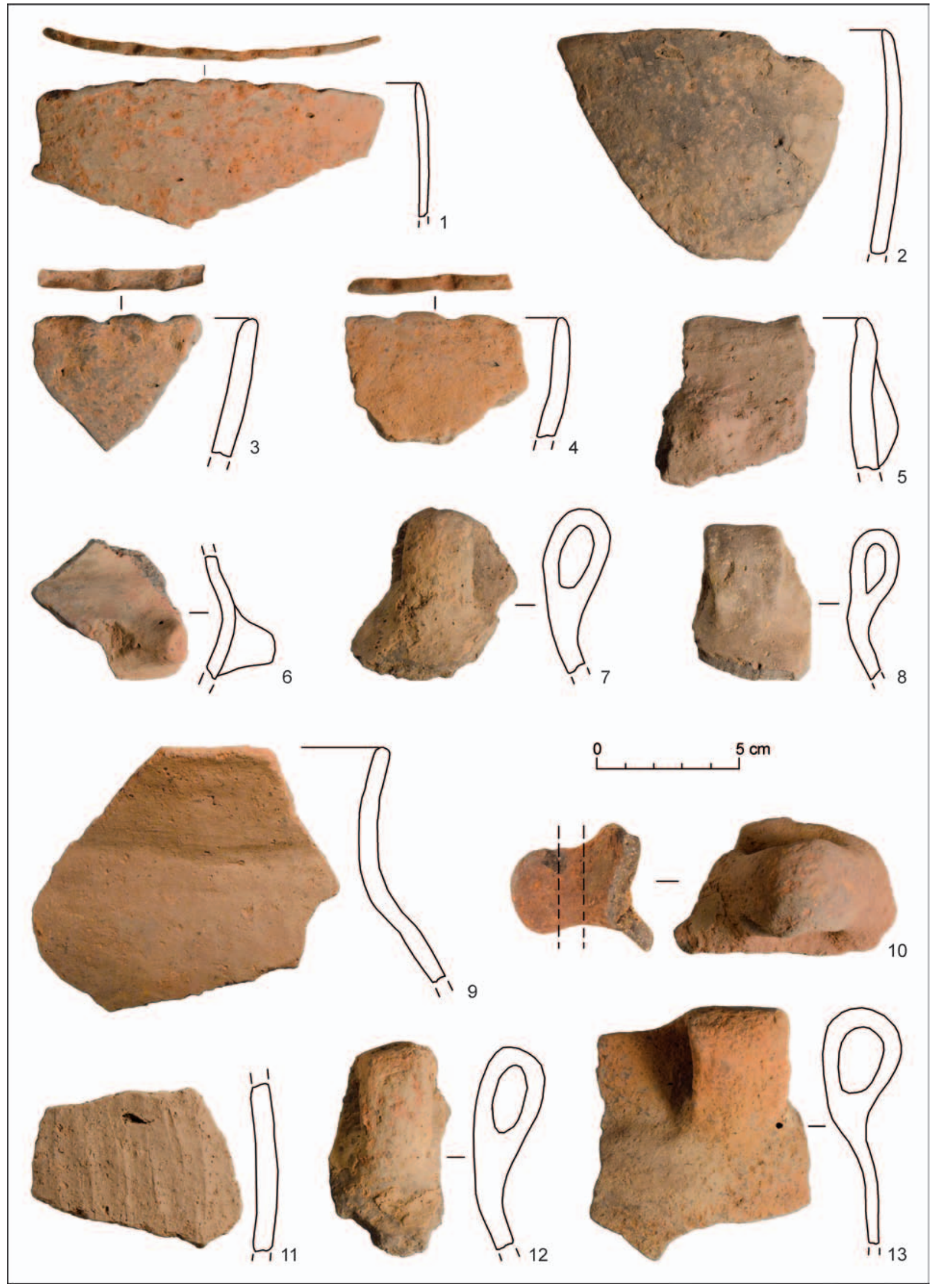

Tab. IV. Dulova Ves-Čergov II. 1, 4, 7, 8, 11-13 - výber nálezov z objektu 2; 2, 3 - výber nálezov z objektu 1; 5, 6, 9, 10 výber nálezov z objektu 1A. Foto A. Marková. 


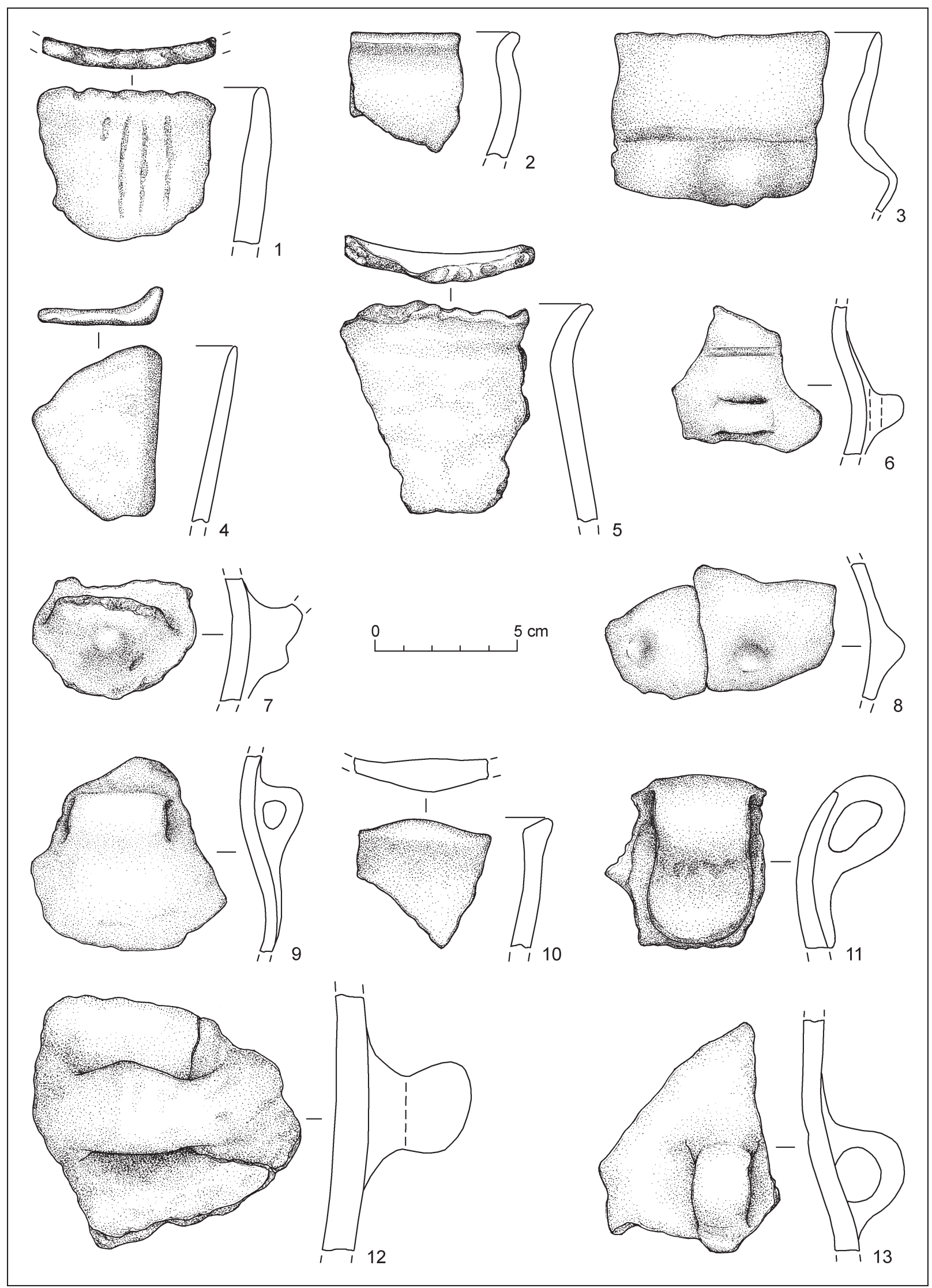

Tab. V. Dulova Ves-Čergov II. 1-7, 9, 10, 12, 13 - výber nálezov z objektu 1; 8 - výber nálezov z objektu 1A; 11 - výber nálezov z objektu 2. Kresba P. Šimčík. 


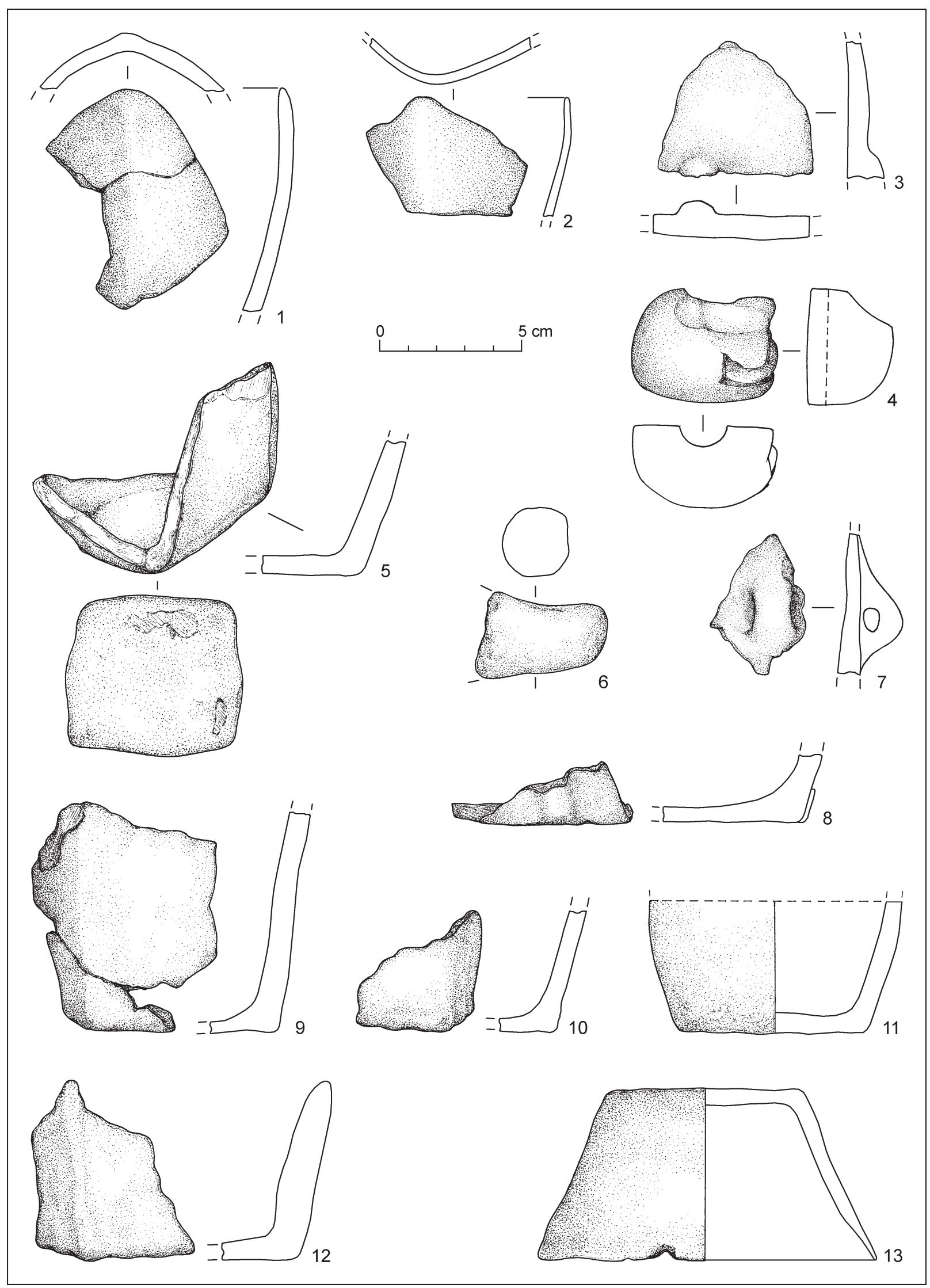

Tab. VI. Dulova Ves-Čergov II. 1, 2, 7, 8, 9, 10, 13 - výber nálezov z objektu 2; 3, 4, 6, 11, 12 - výber nálezov z objektu 1; 5 - výber nálezov z objektu 1A. Kresba P. Šimčík. 


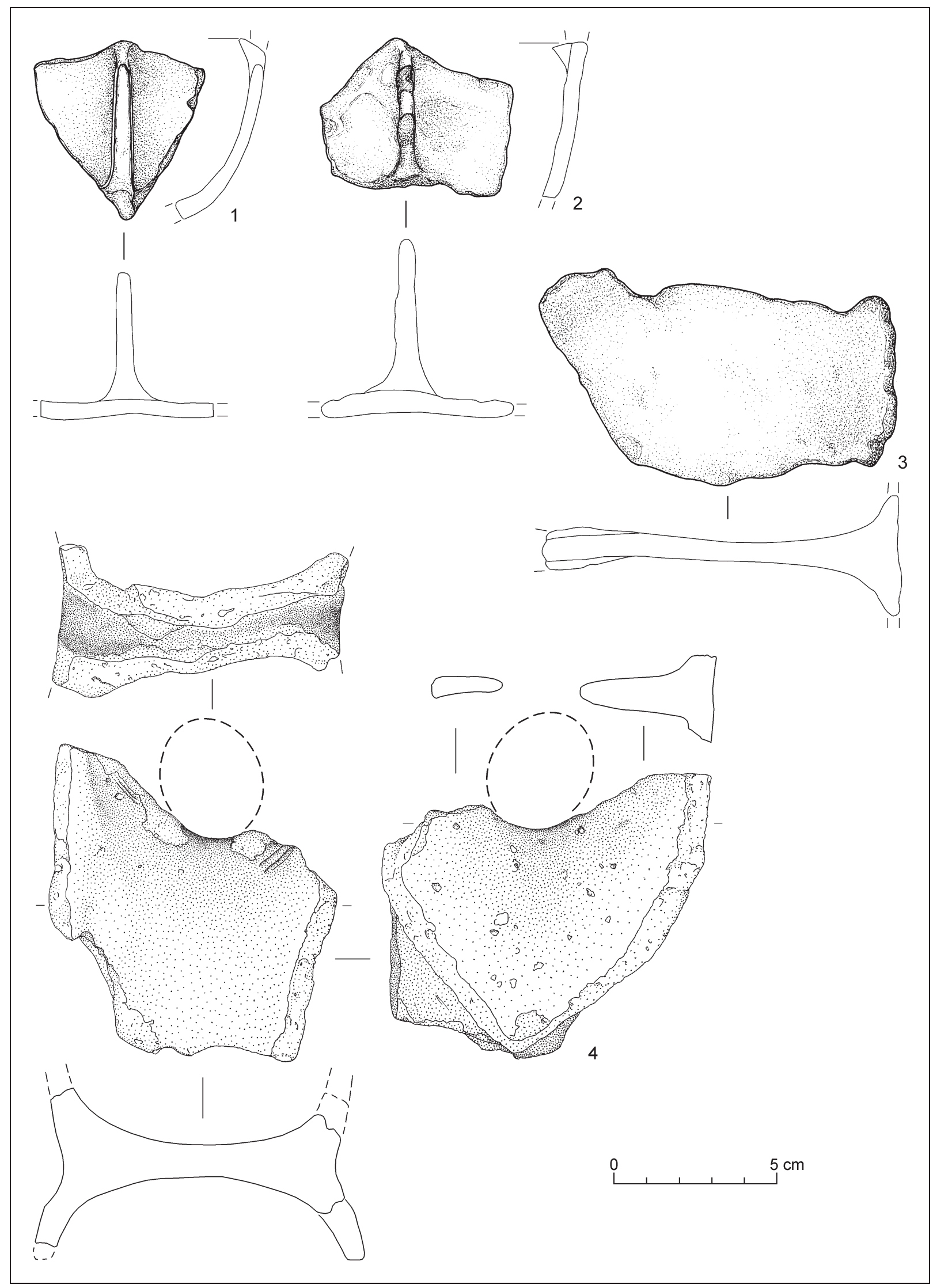

Tab. VII. Dulova Ves-Čergov II. 1-3 - výber nálezov z objektu 2; 4 - výber nálezov z objektu 1. Kresba P. Šimčík. 


\section{LITERATÚRA}

Banner 1956

Bánesz 1970

Bánffy 1997

Blahuta 1963

Bondár 2015

Bognár-Kutzián 1963

Bognár-Kutzián 1969

Brummack 2015

Budinský-Krička 1964

Budinský-Krička 1969

Budinský-Krička 1981

Budinský-Krička/Mačala 1990

Czekaj-Zastawny/Kabaciński/Terberger 2011

Czekaj-Zastawny/Przybyła 2012

Dudaş 1976

Farkaš 2009

Grabowska/Zastawny 2011

Horváthová 2010

Horváthová 2015

Horváthová 2016

Horváthová 2017

Horváthová/Gačková 2019

Horváthová/Hreha 2015

Horváthová/Luštíková 2013
J. Banner: Die Péceler Kultur. Budapest 1956.

L. Bánesz: Eneolitické nálezy z Barce-Svetlej IV. Študijné zvesti AÚ SAV 18, 1970, 326-330.

E. Bánffy: Cult Objects of the Neolithic Lengyel Culture. Connections and Interpretations. Archaeolingua 7. Budapest 1997.

F. Blahuta: Nálezy na sídlisku 2 v Prešove v rokoch 1961-1962. Študijné zvesti AÚ SAV 11, 1963, 153-166.

M. Bondár: The Late Copper Age Cemetery at Pilismarót-Basaharc. István Torma's Excavations (1967, 1969-1972). Budapest 2015.

I. Bognár-Kutzián: The Copper Age Cemetery of Tiszapolgár-Basatanya. Budapest 1963.

I. Bognár-Kutzián: Probleme der mittleren Kupferzeit im Karpatenbecken. Študijné zvesti Aú SAV 17, 1969, 31-60.

S. Brummack,: New Radiocarbon Dates from Eastern Slovakia. The Cases of Malé Raškovce and Barca Baloty. In: S. Hansen/P. Raczky/A. Anders/ A. Reingruber (ed.): Neolithic and Copper Age between the Carpathians and the Aegean Sea. Chronologies and Technologies from the $6^{\text {th }}$ to $4^{\text {th }}$ Millennium BC. International Workshop Budapest 2012. Bonn 2015, 1-19.

V. Budinský-Krička: Pohrebisko z neskorej doby kamennej v Malých Zalužiciach-Lažňanoch. Študijné zvesti Aú SAV 13, 1964, 87-110.

V. Budinský-Krička: Záchranný výskum v rokoch 1965 a 1966 v Barci, okres Košice. Nové Obzory 11, 1969, 231-235, 266-269.

V. Budinský-Krička: Nové nálezy na východnom Slovensku. AVANS 1980, 1981, 35-53.

V. Budinský-Krička/P. Mačala: Nové nálezy na východnom Slovensku. AVANS 1988, 1990, 42-46.

A. Czekaj-Zastawny/J. Kabaciński/T. Terberger: Relacje kulturowe między terenami Wielkiej Niziny Węngierskiej a południowym wybrzeżem Bałtyku. Importy kultury Bodrogkerestzúr na stanowisku Dąbki 9 (Pomorze środkowe). Sprawozdania Archeologiczne 63, 2011, 55-78.

A. Czekaj-Zastawny/M. M. Przybyła: Modlniczka 2. Powiat Krakowski cmentarzysko kultury ceramiki wstegowej rytej i osady neolityczne. Via Archaeologica. Żródła z badań wykopaliskowych na trasie autostrady A4 w Małopolsce. Kraków 2012.

F. Dudaş: Descoperiri eneolitice pe valea crișului alb. Crisia 6, 1976, 21-34. Z. Farkaš: Tri plastiky z badenskej kultúry. Zborník SNM 103. Archeológia 19, 2009, 7-16.

B. Grabowska/A. Zastawny: Materiały kręgu lendzielsko-polgárskiego ze st. 5 w Modlnicy, pow. krakowski. J. Kruk/A. Zastawny (red.): Modlnica, st. 5. Od neolitu środkowego do wczesnej epoki brąu. Via Archaeologica. Żródła z badań wykopaliskowych na trasie autostrady A4 w Małopolsce. Kraków 2011, 95-172.

E. Horváthová: Osídlenie badenskej kultúry na slovenskom území severného Potisia. Nitra 2010.

E. Horváthová: New data to the cognition of the Baden culture settlement in Prešov (north-eastern Slovakia, Šariš). In: M. Nowak/A. Zastawny (ed.): The Baden Culture around the Western Carpathians. Via Archaeologica. Kraków 2015, 381-393.

E. Horváthová: Tretia výskumná sezóna na lokalite Chmelové-Tichá dolina v Prešove. AVANS 2011, 2016, 99, 100.

E. Horváthová: Štvrtá výskumná sezóna v Prešove na lokalite Chmelové-Tichá dolina. AVANS 2012, 2017, 78, 79.

E. Horváthová/L. Gačková: Novoobjavené sídliskové nálezy skupiny Lažňany z Ruskej, okres Michalovce. In: Fragmenty času. Venované Elene Miroššayovej $k 70$. narodeninám. Študijné zvesti AÚ SAV. Supplementum 1. Nitra 2019, 227-254.

E. Horváthová/R. Hreha: Archeologická prospekcia Zemplína vo svetle starších a novších prameňov. Študijné zvesti AÜ SAV 58, 2015, 59-96.

E. Horváthová/L. Luštíková: Záchranný archeologický výskum v Prešove. AVANS 2009, 2013, 103, 104. 
HorváthoválLuštíková 2015

Horváthová/Nevizánsky 2017

Horváthová/Tirpák 2012

Hreha 2016

Chmielewski 2008

Kaczanowska 1980

Kaczanowska 1986

Kaczanowska/Tunia 2009

Kadrow 2013

Kadrow a i. 2003

Kalicz 1980

Kalicz/Horváth 2010

Kamieńska/Kozłowski 1990

Kaminská 1983

Kaminská 2010

Konoplja 1997

Korek 1968

Kozłowski 1968

Kozłowski 1971

Kozłowski 2006

Kruk/Milisauskas 1985

Kulczycka-Leciejewiczowa 1969

Lamiová-Schmiedlová 1964
E. Horváthová/L. Luštíková: Druhá výskumná sezóna v Prešove na lokalite Tichá dolina-Chmelové. AVANS 2010, 2015, 106.

E. Horváthová/G. Nevizánsky: Stránska. Osada badenskej kultúry z obdobia eneolitu v kontexte vývoja severného Potisia. Bratislava - Nitra 2017.

E. Horváthová/J. Tirpák: Predbežné výsledky archeologického výskumu a geofyzikálneho prieskumu na opevnenom sídlisku badenskej kultúry v Prešove. Študijné zvesti AÚ SAV 52, 2012, 119-130.

R. Hreha: Sídliskové objekty kultúry Lažnany-Hunyadihalom v Bidovciach. AVANS 2011, 2016, 100, 101.

T. Chmielewski: Uwagi o chronologii względnej i absolutnej wczesnego i środkowego eneolitu na obszarze Polski południowo-wschodniej i zachodniej Ukrainy. Przeglad Archeologiczny 56, 2008, 41-100.

M. Kaczanowska: Uwagi o surowcach, technice i typologii przemysłu krzemiennego kultury bodrogkereszturskiej i grupy Lažňany. Acta Archaeologica Carpathica 20, 1980, 19-56.

M. Kaczanowska: Materiały typu „Scheibenhenkel“ w Krakowie-Nowej Hucie-Mogile stan. 55. Materiały Archeologiczne Nowej Huty 10, 1986, 43-47.

M. Kaczanowska/K. Tunia: Kultura lendzielska. In: A. Czekaj-Zastawny (ed.): Obrzadek pogrzebowy kultur pochodzenia naddunajskiego w neolicie Polski południowo-wschodniej (5600/5500-2900/BC). Kraków 2009, 259-308.

S. Kadrow: Werteba site in Bilcze Złote: Recent research and analyses. In: S. Kadrow (ed.): Bilcze Złote. Materials of Tripolye Culture from the Werteba and the Ogród Sites. Kraków 2013.

S. Kadrow/M. Sokhackiy/T. Tkachuk/E. Trela: Sprawozdanie ze studiów i wyniki analiz materiałów zabytkowych kultury trypolskiej z Bilcza Złotego znajdujących się w zbiorach Muzeum Archeologicznego w Krakowie. Materiały Archeologiczne 34, 2003, 53-143.

N. Kalicz: Újabb adatok a rézkori Hunyadihalmi csoport időrendjéhez. Neue Beiträge zur Chronologie der kupferzeitlichen Hunyadihalom-Gruppe. A Szolnok Megyei Múzeumok Évkönyve 1979-1980, 1980, 43-62.

N. Kalicz/L. Horváth: Die kupferzeitliche Protoboleráz-Phase (gruppe) im Lichte der neuen ausgrabungen in südwest-transdanubien. In: J. Šuteková/ P. Pavúk/P. Kalábková/B. Kovár (ed.): Panta Rhei. Studies in Chronology and Cultural development of South-Eastern and Central Europe in earlier Prehistory presented to Juraj Pavúk on the occasion of his $75^{\text {th }}$ birthday. Studia Archaeologica et Mediaevelia 11. Bratislava 2010, 407-434.

J. Kamieńska/J. K. Kozłowski: Entwicklung und Gliederung der Lengyel- und Polgar-Kulturgruppen in Polen. Warszawa - Kraków 1990.

L. Kaminská: Nové nálezy z východoslovenských lokalít. AVANS 1982, 1983, 124-126.

L. Kaminská: Čičarovce-Vel'ká Mol’va. Výskum polykultúrneho sídliska. Nitra 2010.

V. Konoplja: Poselennja košylivećkoï hrupy trypilśkoï kultury Błyščanka 2. Naukovi zapysky. Lvivśkyj Istoryčnyj Muzej 6, 1997, 77-98.

J. Korek: Eine Siedlung der Spätbadener Kultur in Salgótarján-Pécskö. Acta Archaeologica Academiae Scientiarum Hungaricae 20, 1968, 37-58.

J. K. Kozłowski: Materiały neolityczne i eneolityczne odkryte na stanowisku Nowa Huta-Wyciąże I. Materiały Archeologiczne Nowej Huty 1, 1968, 13-90.

J. K. Kozłowski: Eneolityczne groby szkieletowe z Nowej Huty-Wyciąża. Materiały Starożytne i Wczesnośredniowieczne 1, 1971, 65-97.

J. K. Kozłowski: Grupa Wyciąże-Złotniki i bezprośrednie oddziaływania polgarskie. In: M. Kaczanowska (red.): Dziedzictwo cywilizacji naddunajskich. Małopolska na przełomie epoki kamienia i miedzi. Biblioteka Muzeum Archeologicznego w Krakowie 1. Kraków 2006, 53-62.

J. Kruk/S. Milisauskas: Bronocice. Osiedle obronne ludności kultury lubelsko-wołyńskiej (2800-2700 lat p. n. e.). Wrocław - Warszawa - Kraków - Gdańsk Łódż 1985.

A. Kulczycka-Leciejewiczowa: Pleszów (Nowa Huta) - osada neolityczna kultury ceramiki wstęgowej rytej i lendzielskiej. Materiaty Archeologiczne Nowej Huty 2, 1969, 7-117.

M. Lamiová-Schmiedlová: Kontrolný výskum v Ostrovanoch. Študijné zvesti AÚ SAV 13, 1964, 233-266. 
Malček 2013

Malček 2016

Malček a i. 2018

Malček/Horváthová/Luštíková, v tlači

Malec/Schreiber 2013

Nevizánsky 2009

Novotná/Soják 2013

Nowak 2014

Patay P. 1968

Patay P. 1974

Patay P. 1999

Patay P. 2005

Patay R. 2004

Pavúk 1998

Peleščyšyn 1998

Podkowińska 1953

Podkowińska 1960

Popa 2009

Prox 1941

Raczky/Siklósi 2013

Rauhut 1975

Roman 1976

Rook 1980

Ruttkay 2006

Soják 2001

Soják 2007

Šiška 1964

Šiška 1968

Šiška 1970

Šiška 1972
R. Malček: Lieskovec-Hrádok. Výšinné sídlisko badenskej kultúry. Nitra 2013.

R. Malček: Badenské osídlenie Cerovej vrchoviny. Nitra 2016.

R. Malček/E. Horváthová/L. Luštíková/R. Hreha: Rekonštrukcia osídlenia v okolí hornej a strednej Torysy vo vybraných obdobiach praveku až včasného stredoveku. Študijné zvesti Aú SAV 64, 2018, 21-52.

R. Malček/E. Horváthová/L. Luštíková: Model osídlenia severovýchodného Slovenska v Povodí Sekčova na podklade dát získaných z prostredia GIS. Slovenská archeológia, v tlači.

J. Malec/P. Schreiber: Dulova Ves. Poloha IBV Čergov. Výskumná správa 61/2013. Archeologický ústav SAV. Michalovce 2013. Nepublikované.

G. Nevizánsky: Zvieracia plastika badenskej kultúry zo Stránskej. Zborník SNM 103. Archeológia 19, 2009, 17-36.

M. Novotná/M. Soják: Vel'ká Lomnica-Burchbrich. Urzeitliches Dorf unter den Hohen Tatra. Nitra 2013.

M. Nowak: Późny etap rozwoju cyklu lendzielsko-polgarskiego w zachodniej Małopolsce. In: K. Czarniak/J. Kolenda/M. Markiewicz (ed.): Szkice neolityczne. Księga poświęcona pamięci prof. dr hab. Anny Kulczyckiej-Leciejewiczowej. Instytut Archeologii i Etnologii Polskiej Akademii Nauk. Wrocław 2014, 239-284.

P. Patay: A fenyeslitkei rezkori temető. A Nyíregyházi Jósa András Múzeum évkönyve 11, 1968, 15-62.

P. Patay: Die hochkupferzeitliche Bodrogkeresztúr-Kultur. Berichte der Roemisch-Germanischen Kommission 55, 1974, 1-71.

P. Patay: A badeni kultúra Ózd-Pilinyi csoportjának magaslati telepei. A Herman Ottó Múzeum Évkönyve 37, 1999, 45-56.

P. Patay: Kupferzeitliche Siedlung von Tiszalúc. Budapest 2005.

R. Patay: Középső rézkori temetkezések és telepnyom Mezőkövesd, Patakra jaró-dűlőből. A Herman Ottó Múzeum Évkönyve 43, 2004, 33-58.

J. Pavúk: Hlavné výsledky výskumu sídliska lengyelskej kultúry v Žlkovciach. Slovenská archeológia 46, 1998, 137-140.

M. A. Peleščyšyn: Pizňotrypil’ske poselenňa bil’a sil Kostanec i Lystvyn na Volyni. In: Volyno-Podil'ski Archeolohični Studuji 1. L'viv 1998, 89-110.

Z. Podkowińska: Pierwsza charakterystyka stanowiska eneolitycznego na polu Grodzisko I we wsi Złota, pow. Sandomierz. Wiadomości Archeologiczne 19, 1953, 1-53.

Z. Podkowińska: Badania v Strzyżowie, pow. Hrubieszów, woj. Lublin, w latach 1935-1937 oraz 1939. Archaeologia Polski 5, 1960, 39-80.

C. I. Popa: Coțofeni culture. A special regard towards Transylvania. Abstrakt dizertačnej práce (Univerzita Alba Iulia. Fakulta histórie a filozofie). Alba Iulia 2009. Nepublikované.

A. Prox: Schneckenbergkultur. Kronstadt 1941.

P. Raczky/Z. Siklósi: Reconsideration of the Copper Age chronology of the eastern Carpathian Basin: a Bayesian approach. Antiquity 87, 2013, 555-573.

D. Rauht: Życie codzienne w neolicie. Wieś na wysokim brzegu Wisly. Z otchłani wieków 41, 1975, 209-232.

P. I. Roman: Cultura Coțofeni. Bucureşti 1976.

E. Rook: Osadnictwo neolityczne w jaskiniach Wyżyny Krakowsko-Częstochowskiej. Materiaty Archeologiczne 20, 1980, 5-130.

E. Ruttkay: Eine Siedlungsgrube mit jungneolithischer inkrustierter Keramik aus Puch-Scheibenfeld, SG und VB Hollabrunn, Niederösterreich Neue Beiträge zur Furchenstichkeramik und zum Scheibenhenkel. Annalen des Naturhistorischen Museums Serie A, 2006, 107, 267-304.

M. Soják: Sídliská ludu badenskej kultúry na Spiši. In: Otázky neolitu a eneolitu našich zemí. Plzeň 2001, 161-190.

M. Soják: Osídlenie spišských jaskýň od praveku po novovek. Nitra 2007.

S. Šiška: Neolitické a eneolitické nálezy z Ostrovian. Študijné zvesti Aú SAV 13, 1964, 71, 76.

S. Šiška: Tiszapolgárska kultúra na Slovensku. Slovenská archeológia 16, 1968, 61-175.

S. Šiška: Nové výskumy na lokalitách lažnianskej skupiny. Východoslovenský pravek 1, 1970, 29-36.

S. Šiška: Gräberfelder der Lažňany-Gruppe in der Slowakei. Slovenská archeológia 20, 1972, 107-175. 
Šiška 1976

Šiška 1982

Šiška 1998

Taras 1999

Terberger/Kabaciński 2010

Torma 1973

Țurcanu 2013

Virag 2013

Vizdal 1977

Vizdal 1980

Vizdal/Derfiňák 2006

Wilk 2004

Wilk 2016

Wilk/Szczepanek 2017

Zakościelna 2002a

Zakościelna $2002 b$

Zakościelna 2006

Zakościelna 2010

Zakościelna/Matraszek 2007

Zalai-Gaál 2016

Zastawny/Grabowska 2014
S. Šiška: Sídlisko mladšej doby kamennej v Prešove-Šarišských Lúkach. Slovenská archeológia 24, 1976, 83-117.

S. Šiška: Sídlisko z mladšej doby kamennej v Šarišských Michalanoch. AVANS 1981, 1982, 272-275.

S. Šiška: Nálezy bolerázskej skupiny na východnom Slovensku. Sborník prací Filosofické fakulty brněnské univerzity M 2, 1998, 125-133.

H. Taras: Wyniki badań wykopaliskowych kurhanu nr 28 na stan. 3 w Tyszowcach, pow. Tomaszów. Archeologia Polski Środkowowschodniej 4, 1999, 74-87.

T. Terberger/J. Kabaciński: The Neolithisation of Pomorania - a critical review. In: D. Gronenborn/J. Petrasch (ed.): Die Neolithisierung Mitteleuropas. Internationale Tagung Mainz Juni 2005. Mainz 2010, 375-405.

I. Torma: Die Boleráz-Gruppe in Ungarn. In: Symposium über die Entstehung und Chronologie der Badener Kultur. Bratislava 1973, 483-512.

S. Turcanu: Antropomorphic and zoomorphic plastic art. In: S. Kadrow (ed.): Bilcze Złote materials of the Tripolye culture from the Werteba and the Ogród sites. Kraków 2013, 53-85.

K. Virag: Archaeological Discoveries from Pecica Belonging to the Bodrogkeresztúr Culture. Ephemeris Napocensis 23, 2013, 177-196.

J. Vizdal: Tiszapolgárske pohrebisko vo Vel'kých Raškovciach. Košice 1977.

J. Vizdal: Potiská kultúra na východnom Slovensku. Košice 1980.

M. Vizdal/P. Derfiňák: Ďalšie nálezy z Vel'kého Šariša. AVANS 2004, 2006, 213.

S. Wilk: Groby kultury lubelsko-wołyńskiej ze stanowiska 2 w Książnicach, powiat Busko Zdrój. Sprawozdania Archeologiczne 56, 2004, 23-305.

S. Wilk: New data about chronology of the impact of the Hunyadihalom-Lažňany horizon on Younger Danubian cultures north of the Carpathian Mountains. Recherches Archéologiques 8, 2016, 7-27.

S. Wilk/A. Szczepanek: The first cremation traces in the Eneolithic period north of the Carpathian Mountains. Sprawozdania Archeologiczne 69, 2017, 353-371.

A. Zakościelna: Przejawy sztuki w kulturze wołyńsko-lubelskej ceramiki malowanej. In: Sztuka pradziejowa ziem polskich. Katalog wystawy. Gniezno 2002, 63-67.

A. Zakościelna: Wykorzystanie krzemienia świeciechowskiego przez społeczności kultur naddunajskich na Wyżynie Lubelskiej. In: Krzemień świeciechowski w pradziejach. Materiaty z konferencji w Ryni, 22.-24. 05. 2000. Studia nad Gospodarką Surowcami Krzemiennymi w Pradziejach 4. Warszawa 2002, 111-122.

A. Zakościelna: Kultura lubelsko-wołyńska. Zagadnienia jej genezy, periodyzacji i chronologii/The Lublin-Volhynian Culture. The problems of its origin, periodization and chronology. In: M. Kaczanowska (red.): Dziedzictwo cywilizacji naddunajskich: Małopolska na przełomie epoki kamienia i miedzi. Biblioteka Muzeum Archeologicznego w Krakowie I. Kraków, 2006, 77-94.

A. Zakościelna: Studium obrzadku pogrzebowego kultury lubelsko-wotyńskiej. Lublin 2010.

A. Zakościelna/B. Matraszek: Die Gräber Lublin-Wolhynien-Kultur aus der Fundstelle „Grodzisko" in Złota, Landkreis Sandomierz. In: J. K. Kozłowski/P. Raczky (ed.): The Lengyel. Polgár and Related Cultures in the Middle/Late Neolithic in Central Europe. Kraków 2007, 411-429.

I. Zalai-Gaál: Tiszapolgár - Bodrogkeresztúr - Hunyadihalom: Wirkungen und Gegenwirkungen am Ende der Hochkupferzeit im Ostkarpatenbecken. In: K. Bacvarov/R. Gleser (ed.): Southeast Europe and Anatolia in prehistory. Essays in honor of Vassil Nikolov on his $65^{\text {th }}$ anniversary. Bonn 2016, 389-402.

A. Zastawny/B. Grabowska: Materiały kręgu lendzielsko-polgárskiego i znaleziska późnoneolityczne ze stan. 10, $11 \mathrm{w}$ Targowisku, pow. wielicki. In: A. Zastawny (red.): Targowisko, stan. 10, 11. Osadnictwo z epochi kamienia. Via Archaeologica. Żródła z badań wykopaliskowych na trasie autostrady A4 w Małopolsce. Kraków 2014, 417-428. 


\title{
The newly discovered settlement features from the younger phase of the Polgár cultural complex from Dulova Ves, Prešov district
}

\author{
Eva Horváthová - Juraj Malec
}

\author{
Summary
}

In 2012 and 2013, the archaeological company Archeológia Zemplín, s. r. o. discovered a previously unknown settlement in the village of Dulova Ves (Prešov district), Čergov II site. Out of nine features, three settlement pits (1, 1A and 2) contained Eneolithic material from the late phase of the Polgár cultural complex.

Features 1 and 2 located $20 \mathrm{~m}$ far from each other showed several similarities. They had large, irregularly oval groundplans (with max. length from 7.4 to $9 \mathrm{~m}$ ), slightly oblique - even perpendicular - walls and shallow - almost flat - bottoms. Each of them contained a smaller pit inside. Such pit was indicated as feature 1A in feature 1; it was located near its northwestern edge. As for feature 2, a much shallower unmarked pit was situated in its central part. Both features' fill also had a similar order of backfill layers. They consisted of the most distinct black loam with admixture of daub and charcoals, a layer of yellow-brown clay loam occurring in some parts near pit walls and, finally, a layer of oily clay loam of grey to brown-grey colour. A certain difference can only be observed in how deep feature $1 \mathrm{~A}$ is sunken. It exceeded the bottom of feature 1 by $0.65-0.68 \mathrm{~m}$. With their groundplans and sizes (reaching 59.43 and $64.75 \mathrm{~m}^{2}$ ), the described features from the younger phase of the Polgár cultural complex from Dulova Ves were significantly different from other features recorded at Cergov II site. We do not find any analogies to them even among chronologically younger Eneolithic features of the Baden culture from the neighbouring site of Chmel'ové near the Tichá dolina valley and - eventually - we do not have any parallels to them in the whole studied region near the middle Torysa valley. With regard to the fact that no burned areas indicating occurrence of heating devices were detected inside them or in their nearest vicinity, they cannot be explicitly interpreted as remains of houses.

2427 archaeological finds including mostly fragments of ceramic vessels (2413 examples in total) come from the analyzed settlement features. Other finds consist of miniature artifacts made of clay (4 specimens) and stone ( 7 specimens). Together with sherds, indistinct pieces of burned clay occured in the backfill layers of settlement features. Organic material was absent. Pottery has been preserved in significantly fragmented condition, which does not allow identification of specific vessel types. For most fragments we were only able to detect thickness of the pottery wall, its surface finish and quality of firing. A more detailed analysis of ceramic material was carried out only on a sample of 115 pottery fragments whose preserved profiles and some decorative elements allowed at least partial comparison with the assortment of the Lažňany group or the Hunyadihalom culture's pottery products. The selected archaeological material is presented in graphic form in plates I-VII.

As for the types of pottery included in the collection of finds, bowls, cups, pots, amphoras/small amphoras, quadrangular vessels, divided vessels, storage vessels and lids were used at the settlement in Dulova Ves. A unique fragment from an untypical oval vessel with a chipped off hollow pedestal and a large opening in the bottom was also discovered. Miniature artifacts made of clay discovered in the fill of feature 1 included fragments of two conical spindle whorls, a fragment of an artifact with an unidentified function and one zoomorphic figurine. As for lithic artifacts, there was a blade end-scraper made of Volhynian flint, an obsidian bladelet, a fragment of an axehammer made of limnosilicite sandstone and a whetstone with traces of smoothing. In feature 2, two damaged blades from obsidian and smaller pieces of opal raw material (1 exemplar) and Jurassic flint ( 2 exemplars) occurred.

The evaluated finds from Dulova Ves represent the youngest horizon of settlement of the Polgár cultural complex. They are clearly syncretic, with features of elements penetrating from other cultures. Among pottery products, identifying features of the Lažany group - comparable with the Hunyadihalom culture pottery in many aspects - prevail (bowls with considerably rounded bodies and distinctly offset cylindric or slightly funnel-shaped necks, oval or trough-shaped bowls, pots with suggested necks and two robust handles near the edges, quadrangular vessel shapes in form of chalices and lids; as for decorative elements, there are edges decorated with imprints or cuts, bulges embossed from the inside, boat-shaped handles and handles of the Schibenhenkel type).

Several of the above mentioned features occur also on pottery from the youngest phase of the Wyciąże-Złotniki group and the Lublin-Volhynian culture (phase III). Fragments of thin-walled cups with S-shaped profiles, low necks and bulbous bodies, pointed protuberances reaching above the vessel edge, lingular protuberances on the edges, longitudinal blunt protuberances and small semiglobular protuberances are interpreted as undoubtedly foreign elements in the evaluated assemblage. We assume that the above described attributes show similarity with the Lublin-Volhynian pottery, which represented the furthermost fraction of the Polgár influence north of the Carpathians. Another evidence of heterogeneity of the archaeological material from Dulova Ves lies in the discovery of the zoomorphic figurine which is as unique among the finds of the Lažňany group as the Lublin-Volhynian animal figurine from the site of Tiszowice (eastern Poland). Both figurines - without preserved heads - are strikingly similar to zoomorphic idols from several representations from the Tripolye culture. The legacy of the influence from this cultural environment is visible not only in the lithic industy. It can be exceptionally recognized also on pottery from the sites of Hołyszów, Strzyżów and Košice-Barca. 
The expansion of influence and penetration of a certain part of the Polgár population northwards, especially to the region of Malopolye, has been associated with the Tiszapolgár and mainly Bodrogkeresztúr cultures for a long time. It followed from numerous finds of flint industry occurring at sites in the Carpathian inland; on the other hand, copper artifacts of the Inner Carpathian provenance appeared more and more frequently north of this territory. A high level of mobility of the Bodrogkeresztúr culture can be noticed also in the Wyciąże-Złotniki group. Finds of amber pearls at the cemetery in Lažňany and fragments of Bodrogkeresztúr pottery at the site of Dąbki suggest possible more remote contacts of the Polgár population with Baltic regions. Results of modern investigations support our opinion that participation of the population from the youngest phase of the Polgár cultural complex in further expansion of cultural patterns from the Carpathian Basin northwards was no lesser. An excelent example of mutual cultural contacts between the Hunyadihalom-Lažňany horizon and the Lublin-Volhynian culture is represented by two recently published biritual burials from site 2 at the burial ground in Książnicach, site 2 (burials 7 and 14). In the grave goods of inhumation burial 7, we can see a great example of merging (or prevalence) of significant young Polgár elements with cultural-identifying features of the Lublin-Volhynian culture. A rich collection of jewels including five copper artifacts was found in the burial and near it. The uniqueness of burial 14 can be seen in the fact that it is the first Eneolithic cremation burial in southeastern Poland which was discovered at a Lublin-Volhynian culture's burial ground. It might suggest that the Hunyadihalom-Lažňany horizon's influence was so intense that it left a trace in a foreign cultural environment in form of ocassionally tolerated deviations in the burial rite. Based on the latest modifications of the radiocarbon chronology, mutual interactions of the Lublin-Volhynian culture, Lažňany group and Hunyadihalom culture might have been taking place in the period between 4000/3950 and 3800/3750 cal. BC. The newly obtained radiocarbon data specify the duration of the Wyciąże-Złotniki group and limit it within years 4200-3800/3750 BC.

Fig. 1. Village of Dulova Ves, Prešov district. Location of the site on a blank map of Eastern Slovakia and section of a map, scale $1: 10000$.

Fig. 2. Location localization. 1 - sites on a map; 2 - orthophoto map. A - village of Dulova Ves, Prešov district, location Čergov; B - Prešov-Solivar, Prešov district, location Chmelové-Tichá dolina.

Fig. 3. Village of Dulova Ves, Prešov district. Section from the excavation's situation plan with detected locations of Eneolithic features 1, 1A and 2. Plan by J. Malec.

Fig. 4. Village of Dulova Ves, Prešov district. 1 - drawn documentation of features 1 and $1 \mathrm{~A} ; 2$ - drawn documentation of feature 2. Legend: a - black-grey loam with admixture of daub and charcoals; b - yellow-brown clay loam; cgrey clay loam; $\mathrm{d}$ - grey-brown loam with admixture of daub and charcoals; e-yellow-brown mixed loam; $\mathrm{f}$ - oily brown-grey loam.

Fig. 5. The original state of the analyzed pottery from features 1, 1A and 2.

Fig. 6. Comparison of numbers of unclassified pottery from features 1, 1A and 2 with regard to thickness of the ceramic mass.

Fig. 7. Numbers of identified ceramic types of vessels in features 1, 1A and 2.

Fig. 8. Numbers of identified ceramic types of vessels and miniature artifacts in feature 1.

Fig. 9. Numbers of identified ceramic types of vessels in feature 1A.

Fig. 10. Numbers of identified ceramic types of vessels in feature 2.

Pl. I. Dulova Ves-Čergov II site. Selected finds from feature 1. Photos by A. Marková.

Pl. II. Dulova Ves-Čergov II site. 1-3 - selected finds from feature 2; 4-6 - selected finds from feature 1A. Photos by A. Marková.

Pl. III. Dulova Ves-Čergov II site. 1, 2, 5-7 - selected finds from feature 1; 3, 4 - selected finds from feature 2. Scale: $\mathrm{a}-1-4 ; \mathrm{b}-5-7$. Photos by A. Marková, drawings by P. Šimčík.

Pl. IV. Dulova Ves-Čergov II. 1, 4, 7, 8, 11-13 - selected finds from feature 2; 2, 3 - selected finds from feature 1; 5, 6, 9, 10 - selected finds from feature 1A. Photos by A. Marková.

Pl. V. Dulova Ves-Čergov II site. 1-7, 9, 10, 12, 13 - selected finds from feature 1; 8 - selected finds from feature 1A; 11 - selected finds from feature 2. Drawings by P. Šimčík.

Pl. VI. Dulova Ves-Čergov II site. 1, 2, 7, 8, 9, 10, 13 - selected finds from feature 2; 3, 4, 6, 11, 12 - selected finds from feature $1 ; 5$ - selected finds from feature 1A. Drawings by P. Šimčík.

Pl. VII. Dulova Ves-Čergov II site. 1-3 - selected finds from feature 2; 4 - selected finds from feature 1 . Drawings by P. Šimčík.

PhDr. Eva Horváthová, PhD.

Archeologický ústav SAV Nitra

OVVS Košice

Hrnčiarska 13

SK - 04001 Košice

ehorvath@saske.sk
Mgr. Juraj Malec, PhD.

Trenčianske múzeum v Trenčíne

Mierové námestie 46

SK - 91250 Trenčín

jumal.tn@gmail.com 
